\title{
Bibliografia de J. X. Carvalho de Mendonça*.
}

\author{
As referências numéricas são do fichário da Biblio- \\ teca da Faculdade de Direito da USP.
}

\section{Obras.}

1. Ação possessória - apelação, prazo para apresentação dos autos na instância superior, excepção em favor de menores - "Constituto possessório" - "Clausula Constituti" - embargos de restituição. (Parecer) - Typografia Andrade \& Mello - São Paulo - 1905 - 1 folheto - S5-23-4.

2. Armazens Geraes - Exposição de motivos e projeto de lei - Typografia do "Jornal do Comercio" - Rio de Janeiro 1901 - 1 folheto S3-25-4.

3. Em comemoração do Tratado de direito comercial brasileiro - Tipografia do Anuário do Brasil - Rio de Janeiro - 1928 - 1 volume - Q15-16-6.

4. Das Fallencias e dos meios preventivos de sua declaração Typografia Brasil — São Paulo - 1899 - 2 volumes - N9-12-18 e 19.

5. Deposito de genero - Móra - Ação Ordinária - Santos (Razões Finais) Tipografia King - São Paulo - 1892 - 1 folheto - S5-23-22.

6. Dos livros dos comerciantes - Estudo theorico pratico Typografia Carlos Gerichke - São Paulo - 1 volume S10-26-29.

7. Dos livros dos comerciantes - Carlos Gerke \& Rotschild, editores — São Paulo - 1906 - 1 volume - N11-16-21.

8. Executivo fiscal de impostos de dividendo - Ilegalidade do tributo - Supremo Tribunal Federal - Apelação civel numero

* Na redação desta bibliografia foi conservada a ortografia original dos trabalhos. 
3.753 - Distr. Federal - (alegações) Tipogr. do Jornal do Comercio - Rio de Janeiro - 1920 - 1 folheto - S14-25-37.

9. Exibição judicial de livros - Supremo Tribunal Federal Agravo (minuta) - Tipografia Cardoso, Filho \& Cia. - São Paulo - 1908 - S7-21-6.

10. Homenageando um aposto do direito - A memoravel sessão com que o Instituto dos Advogados de São Paulo recebeu o grande jurisconsulto brasileiro José Xavier CARvalHo de MenDONÇA, conferindo-lhe o titulo de socio honorario, em 9 de setembro de 1925 - Tipografia do Jornal do Comercio Rio de Janeiro - 1925 - 1 folheto - S11-20-2.

11. Nulidade dos contratos cambiaes estabelecida na lei $n .359$ de 30 de dezembro de 1895 - Orçamento da receita federal de 1896 - A excepção de jogo - Comarca de Santos - Acção ordinaria - (alegações finaes) - Tipografia de Espindola, Siqueira \& Cia. - São Paulo, 1897 - 1 folheto - S5-23-4.

12. Opiniöes de jurisconsultos nacionaes, a respeito das obras publicas pelo Dr. SPENCER VAMPRÉ - Livr. Magalhães São Paulo - 1917 - 1 folheto - S12-25-6.

13. Pareceres - Livraria Editora Freitas Bastos - Rio de Janeiro - Prefacio do Dr. Waldemar FerReira - Colligidos por achiles Bevilacoua e Roberto Carvalho de Mendonça -

I 1-13-1 - 1933 - volume I - fallencias -

I $1.132-1934$ - volume II - sociedades -

I 1.13-3 - 1936 - volume III - direito comercial.

14. Póde um Estado da Federação tributar produtos de outro Estado que sejam exportados através de seu território? Supremo Tribunal Federal - Ação originaria numero 10, entre o Estado de São Paulo e o de Minas Geraes - (Memorial do Estado de São Paulo) - Cardozo Filho \& Cia, editor S. Paulo - 1910 - 1 volume - S14-20-33.

15. Póde um Estado da Federação tributar producto de outro Estado, que sejam exportados através do seu território? Supremo Tribunal Federal - Ação originaria n. 10, entre os Estados de São Paulo e Minas - (alegaçōes) - Sem mencionar editor - Rio de Janeiro - 1910 - 1 volume - S11-21-7.

16. Os problemas das sociedades anonimas - Empresa Grafica da Revista dos Tribunais - São Paulo - 1931 - 1 volume - N9-13-21.

17. Renovação do registro de marca - O caso da marca "Balança howe" - (pareceres) - Empresa Grafica da Rev. dos Tribunais - São Paulo - 1929 - 1 folheto - N4-25-27. 
18. Tratado de direito comercial brasileiro - $6 .^{a}$ edição posta em dia por Roberto CaRvalho de Mendonça - Rio de Janeiro, Freitas Bastos, 1954-58-9 v. em 12, $23 \mathrm{~cm}$. - Os vols. 3 a 9 são da $5^{\text {a }}$ edição.

Notas de rodapé

Bibliografia.

Conteúdo:

v. 1 Introdução - Dos atos do comércio.

v. 2 a 4 -Dos comerciantes e seus auxiliares.

v. 5 t.1 e 2 - Das coisas do direito comercial.

v. 6 t.1 a 3 - Das obrigações, dos contratos e da prescrição em matéria comercial.

v. 7 e $8-D a$ fallencia e da concordata preventiva.

/v. 9/ Indice geral, alfabético e remissivo.

S. C. $347.70(81)$

19. Tratado de Direito Comercial Brasileiro - Livr. Edit. Freitas Bastos - Rio de Janeiro - 1934-1938 - 3.a edição posta em dia por Achilles Bevilacqua e Roberto Carvalho de Mendonça - 8 volumes em 11 partes -

06-14-7 - volume I - Introdução - dos Actos do Comercio. 06-14-8 - volume II - Dos comerciantes e seus auxiliares. 06-14.9 e 10 - volumes III e IV - Das sociediades comerciais. 06-14-11 - volume V - $1 .^{\mathrm{a}}$ parte - Do estabelecimento comercial - Das mercadorias - Da propriedade industrial. 06-14-12 - volume $\mathrm{V}-2 \mathrm{.}^{\mathrm{a}}$ parte - Do dinheiro $e$ dos titulos de crédito e especialmente dos negociaveis no comercio. Letra de cambio, nota promissoria - cheque - bilhete de mercadorias e conhecimento de deposito e "warrant" 06-14-13 a 15 - volume VI - partes $1 .^{\mathrm{a}}, 2^{\mathrm{a}}$ e $3 .^{\mathrm{a}}$. - Das obrigações, dos contratos e da prescrição em matéria comercial.

06-14-16 e 17 - volumes VII e VIII - $D a$ fallencia e da concordata preventiva — Da materia penal em relação á falencia e á concordata preventiva.

06-14-18 - 1940 - Indice geral, alphabético e remissivo.

20. Tratado de direito comercial brasileiro - 3.a edição posta em dia por Achilles Bevilacqua e Roberto Carvalho de Mendonça. Rio de Janeiro, Freitas Bastos, $1934-38$ - 8 v. em $11.23 \mathrm{~cm}$.. Os vols. 5, 6, 7 e 8 são da $2 .^{a}$ edição, 1934 .

Notas de rodapé

Bibliografia.

Conteúdo:

v. 1 T5-24-1 - Dos Actos do Comercio.

v. 2 a 4 T5-24-2 a 4 -Dos comerciantes e seus auxiliares.

v. 5 t1 e 2 T5-24-5 e 6 - Das cousas no direito comercial. 
v. 6 t.1 a 3 T5-24-7 a 9 - Das obrigações, dos contratos e da prescrição em materia comercial.

v. 7 e 8 T5-24-10 e 11 - Da falencia e da concordata preventiva.

21. Tratado de Direito Comercial Brasileiro. - Livraria Editora Freitas Bastos - Rio de Janeiro - 2. ${ }^{\text {a }}$ edição posta em dia por Achilles Bevilacqua e Roberto Carvalho de Mendonça - 8 volumes em 11 tomos.

06-13-6 - 1933 - vol. I - Introdução - Dos actos de comercio.

06-13-7 a 9 - 1933 - vols. II, III e IV - Dos comerciantes e seus auxiliares.

06-13-10 e 11 - 1934 - vol. V - Das cousas no direito comercial.

06-13-12 a 14 - 1934 - vol. VI - Das obrigaçöes, dos contratos e da prescrição em materia comercial.

06-13-15 e 16 - 1934 - vols. VII e VIII - Da falencia e da concordata preventiva - Da materia penal em relação á fallencia e á concordata preventiva.

22. Tratado de direito comercial brasileiro - Typografia do Jornal do Comercio - Rio de Janeiro - 1925-1930 - 2. ${ }^{\text {a }}$ edição - 1. ${ }^{\text {a }}$ parte -2 volumes - N9-12-1 e 2.

23. Tratado de direito comercial brasileiro - Cardoso Filho \& Cia. - São Paulo - 1910 - volumes 8 - N9-14-19 a 26.

24. Tratado theorico e pratico das justiças de paz - B. L. Garnier editor - Rio de Janeiro - 1889 - 1 volume - S2-25-5.

\section{Artigos (direito administrativo).}

25. Camaras Municipaes - Atribuições - Salubridade publica - Gazeta Juridica, S. Paulo - 1901 - vol. 27 - página 297 - R16-23-15.

26. Sobre cheques cruzados para o pagamento do imposto de renda - in Relatorio da Assoc. Bancaria - Rio de Janeiro - 1927 - pagina 28 - I3-21-29.

27. Concessão administrativa - Excesso de prazo marcado para a construção de obras publicas sob regimen da concessão administrativa - Móra - Recisão do contrato. o governo, por seu arbitrio, não póde modificar contratos em que é parte. (Parecer) - in O Direito - Rio de Janeiro - 1904 - vol. 94 - pagina 317 - P13-23-20.

28. Concessão de obras públicas - in Revista do Supremo Trib. Federal - Rio de Janeiro - 1925 - Discurso proferido na 1. ${ }^{a}$ 
reunião da Seção de Direito Administrativo do Congresso Juridico de 1922 - vol. 81 - pagina 341 - 012-10-3.

29. Concessão de rêde telephonica - Clausula de preferencia (Pareceres) - in Revista Forense - Bello Horizonte - 1913 - vol. 21 - pagina 167 - M214-19.

30. Funcionário publico em disponibilidade - Compulsoria Vencimentos - Lente do Gynasio Mineiro, nomeado no regime da lei n. 41 de 1892 - (Pareceres) - in Revista Forense Bello Horizonte - 1928 - volume 51 - pagina 400 - M3-14-19.

31. Imposto sobre dividendos - (Pareceres) - in Revista de Direito - Rio de Janeiro - 1920 - vol. 55 - pagina 255 N1-15-2.

32. Imposto sobre a renda - Ha imposto a pagar sobre a quantia retirada do fundo de reserva para preencher as ações que vão ser distribuidas pelos acionistas? - (Parecer) - in Memorial da apelação civel numero 5.593 - Rio de Janeiro - 1927 pagina 7 - S6-22-21.

33. Imposto sobre a renda - O que são lucros liquidos ou reaes - Definição - Assento desta em disposição de lei - Disponibilidade dos lucros - Lucros ficticios - Inexistencia de fundamento legal para cobrança - Desvirtuamento do instituto (Pareceres) - in Revista de Direito - Rio de Janeiro 1926 - volume 79 - pagina 575 - N1-15-27.

34. Imposto de vendas mercantís - O imposto de compra e venda mercantil recae sobre o comissario e não sobre o comitente - (Parecer) - in Pareceres - Rio de Janeiro - 1936 vol. III - pagina 337 - I1-13-3.

35. Imposto - Transferência das acções das companhias ou sociedades anonimas que exploram predios rusticos ou urbanos, situados no Estado - Companhias ou sociedades anonimas que exploram a industria de energia elétrica - Intelligencia do artigo 3 , número 8 , da lei numero 1.249 de 31 de dezembro de 1910 - Não está sujeita á tributação constante do artigo 3., numero 8 , da lei estadual numero 1.249 , de 31 de dezembro de 1910, a transferência das ações de sociedadeş anônimas que tem por objeto a exploração e distribuição de energia eletrica, embora utilizando, para tal fim, dos imóveis necessários ao exercicio e desenvolvimento dessa actividade idustrial in Revista dos Tribunais - S. Paulo - 1929 - vol. 70 pagina 524 - N5-15-5.

36. Isenção de impostos, no Estado por onde exportar, sobre a produção dos outros Estados - Legitimidade do Estado exportador para pedir a nullidade dos actos do Estado transmissor 
prejudiciaes ao comercio dos produtos exportados - Litigio entre o Estado de São Paulo e o Estado de Minas Geraes - (Allegaçōes) - in O Direito - Rio de Janeiro - 1912 - vol. 119 - pagina 374 - P15-23-20.

37 Intervenção nos Estados - Responsabilidade da União Federal pelos actos do interventor - Ação de perdas e damnos - Justiça competente - Intervenção no Amazonas - (Pareceres) - in Revista de Direito - Rio de Janeiro - 1929 - volume 92 - pagina 413 - N1-14-12.

38. Os juizes de direito do extinto regimen, não aproveitados na magistratura atual, são juizes federaes - Seus vencimentos não foram fixados pela Constituição e podem ser aumentados pelo Congresso - (Pareceres) - in O Direito - Rio de Janeiro - 1910 - vol. 113 - pagina 595-596-598 - P15-23-14.

39. Os juizes de direito em disponibilidade - $O$ aumento de seus ordenados - (Pareceres) - in Os juizes de direito em disponibilidade - Rio de Janeiro - 1911 - paginas 67, 69 e 70 - S1-23-25.

40. As municipalidades podem hypotecar bens de seu dominio industrial - Gazeta Juridica, São Paulo - 1904 - vol. 34 gina 195 - R16-23-22.

41. Recurso extraordinario - Imposto cobrado ilegalmente Restituição de indebito - (Pareceres) - in Rev. Forense - B. Horizonte - 1910 - vol. 13 - pagina 5 - M2-14-11.

42. Reforma compulsória estabelecida para o exercito - Se é aplicavel á Brigada Policial - in Pandectas Brasileiras Rio de Janeiro - 1927 - volume 3. - segunda parte - pagina 72 - H1-16-4.

43. Requisição de linhas ferreas - Quando póde ser feita pelo governo - (Pareceres) - in Rev. dos Tribunaes - São Paulo - 1919 - vol. 29 - pagina 171 - N5-17-29.

44. Terras devolutas e terras plarticulares - 0 registo feito na repartição de terras implica o reconhecimento expresso, por parte do Estado, do dominio de outrem - Validade do regis to feito por publicas formas - Nulidade da alienação e arrendamento das terras de dominio particular feitos pelo Estado - (Parecer) - in As propriedades do Barão de Antonina - São Paulo, 1922 - pagina 26 - S1-23-20.

45. Os terrenos de marinha e os interesses da União, dos Estados $e$ das Municipalidades - in O Direito - Rio de Janeiro - 1901 - volume 85 - pagina 473 - P13-23-11. 
46. Terrenos de marinha - Situação juridica dos possuidores desses terrenos - in Revista dos Tribunaes - São Paulo 1921 - volume 5 - pagina 291 - N5-16-5.

\section{Direito Cambial.}

47 Ação regressiva do endossante contra o aceitante - $\mathrm{O}$ endossante que paga tem ação regressiva contra $c$ aceitante da cambial, não obstante haver sido este exonerado pelo portador - (Parecer) - in Pareceres - Rio de Janeiro 1936 - volume III - pagina 81 - I1-13-3.

48. Aval não é fiança - Aval não é fiança, dela se diferenciando substancialmente, na forma e nos efeitos - Não se lhe aplica, portanto no art. 235, III, do código civil - (Parecer) - in Pareceres - Rio de Janeiro - 1936 - volume III — pagina 127 - I1-13-3.

40. Avalista do aceitante da letra ou do emitente da nota promissoria - E desnecessário o protesto para manter a responsabilidade do avalista da letra ou emitente da nota promissória - (Parecer) - in Pareceres - Rio de Janeiro 1936 - volume III - pagina 153 - I1-13-3.

50. Cambial - Endosso para cobrança - Selo - o endosso-mandato, isto é, por procuração ou em cobrançả, posterior ao vencimento do titulo endossado, deve ser selado? No caso afirmativo, o selo deve ser proporcional, ao valor do titulo, ou deve ser o selo fixo prescrito para as procurações? (Pareceres) - in Revista Forense - Belo Horizonte - 1925 - vol. 44 - pagina 431 - M3-14-12.

51. Compra e venda de cambiaes - Contratos nullos e simulados - (Parecer) - in Compra e venda de cambiaes - Rio de Janeiro - 1920 - pagina 40 - S1-25-23.

52. As contas assinadas - (Parecer) - in Revista do Supremo Tribunal Federal — Rio de Janeiro - 1915 - vol. 3 - parte 2. ${ }^{\mathrm{a}}$ - pagina 275 - O12-11-6.

53. Contas assinadas - Faturas - Duplicatas - selo proporcional - Decreto numero 11.537 de 17 de março de 1915 - Inteligencia - Disposição constitucional - (Parecer) - in Revista de Direito - Rio de Janeiro - 1915 - volume 36 pagina 435 - N1-16-10.

54. Direito regressivo do tomador de cambial sacada por conta de terceiro e apresentada fóra do prazo para aceite - O sacador por conta e ordem de terceiro é cambialmente, responsavel, pelo só fato da assinatura do saque - A ação regressiva do tomador nesse caso, não poderá ser executiva, si a cambial 
for apresentada fóra de prazo para aceite - A ação ordinária de locuplemento tambem não poderá ser proposta contra o sacador por conta de terceiro, si ele provar que entregou a esse terceiro o preço da cambial - (Parecer) - in Pareceres - Rio de Janeiro - 1936 - vol. III - página 251 - I1-13-3.

55. Endosso, aceite ou aval - Mandatario - Poderes especiaes Actos de gerencia - (Parecer) in Revista de Direito - Rio de Janeiro - 1914 - vol. 34 pagina 25 - N1-16-8.

56. Endosso com clausula - Valor em conta - A clausula Valor em conta - É inutil, porém não vicia o endosso nem obsta a transmissão da nota promissória - Parecer) - in Pareceres - Rio de Janeiro - 1936 - volume III — pagina. 131 - I1-13-3.

57 Endosso falso - Póde o aceitante recusar o pagamento, quando falso o endosso que transferir ao portador a cambial (Parecer) - in Pareceres - Rio de Janeiro - 1936 - volume III - pagina 89 - I1-13-3.

58. Endosso com a formula "valor em Conta" - in Revista Forense - Belo Horizonte - 1916 - volume 26 - pagina 246 - M2-14-24.

59. Endosso por procuração - Não está sujeito a selo - Lançamento da duplicata assinada a credito do comprador - Inadmissibilidade - Titulos de crédito - Quando não pódem ser impostos como moeda - (Pareceres) - in Revista de Direito -Rio de Janeiro - 1925 - vol. 76 - pagina 73 - N1-15-24.

60. Endosso - De titulos a prazo e á vista - isenção de selo (Parecer) - in Relatorio da Associação Bancaria - Rio de Janeiro - pagina 1926-/45-13 - 21-28.

61. Natureza do aval - Aval não é fiança, pelo que póde ser concedido pelo marido independentemente do consentimento da mulher - (Parecer) - in Pareceres - Rio de Janeiro 1926 - vol. III — pagina 183 - I1-13-3.

62. Nota promissória - Bilhete de mercadoria - Crédito mercantil - in Revista de Direito - Rio de Janeiro - 1907 - vol. 4 - pagina 369 - N1-17-4.

63. Nota promissória - Protesto no vencimento - Desnecessidade de outro para fundamentar a fallencia do emissor (Parecer) - in Revista de Direito - Rio de Janeiro - 1936 - volume 121 - pagina 67 - N11-13-10.

64. Obrigação cambial - Aceite por procurador - Poderes especiaes - in Revista dos Tribunaes - São Paulo - 1917 vol. 21 - pagina $164-\mathrm{N} 5-17-21$. 
65. Prisão do sacado que recusa restituir a letra recebida para aceite - inadmissível caução fidejussoria para excluir a prisão do sacado que recusa restituir a letra recebida para aceite - Feito o deposito, para evitar a prisão, o portador o levanta logo, ainda antes do vencimento, porque o fato importa no vencimento - in Pareceres - Rio de Janeiro - 1936 volume III - pagina 99 - I1-13-3.

66. Provisão nas letras de terra; protesto; responsabilidade do sacado - O princípio: o aceite supõe a provisão - (Parecer) - in O Direito - Rio de Janeiro - 1903 - volume 90 pagina 410 - P13-23-10.

67 Remissão da divida do aceitante antes do vencimento da cambial. A remissão da divida do aceitanté, antes do vencimento da cambial exonera todos os co-obrigados - (Parecer) - in Pareceres - Rio de Janeiro - 1936 - vol. III - pagina 85 I1-13-3.

68. Selo das duplicatas endossadas para cobrança - in Revista do Supremo Tribunal Federal - Rio de Janeiro - 1924 volume 78 - pagina 474 - O16-11-16.

\section{Direito Civil.}

65. Alteração do nome civil das pessôas fisicas - $\mathbf{E}$ licito ás pessoas fisicas alterar o seu nome civil, para que possa ser mantida uma firma social - Não é licito porém, ter dois nomes, um para efeito civís e outro para efeitos comerciaes - in Pareceres - Rio de Janeiro - 1934 - volume II - pagina 401 - 11-13-2.

70. O arrematante de um imovel rural não é obrigado a respeitar uma concessão de uso de agua nascida no imovel, feita pelo antigo proprietário depois que este havia hipotecado o dito imovel - Si o concessionário fôr uma municipalidade, esta terá que pagar ao arrematante o valor da concessão, que contudo não lhe poderá ser cassada - Ação de que o arrematante deve lançar mão é a subsidiaria de reivindicação - $O$ uso de agua não constitue servidão predial nem servidão pessoal de uso - (Pareceres) - in O Direito - Rio de Janeiro - 1910 - volume 113 - pagina 124-128 e 132 - P15-23-14.

71. Cessão de arrendamento - Cessão de arrendamento por parte do arrendador não importa novação subjectiva nem exige consentimento do arrendatario - (Parecer) - in Pareceres - Rio de Janeiro - 1933 - volume I - pagina 55 - I1-13-1.

72. A clausula resolutiva expressa nos contratos - $\mathrm{O}$ ato comissorio nos contratos hipotecarios - A concessão con- 
tratos e as obrigações do Estado concedente - A guerra como motivo de força maior - (Pareceres) - in Revista Forense Bello Horizonte - 1920 - volume 33 - pagina 57 - M3-14-1.

73. Contrato com reserva de dominio - (Parecer) - Appenso á reclamação reivindicatória do Dr. Gilberto Sampaio - São Paulo - 1928 - pagina 39 - N3-24-18.

74. Da responsabilidade da União Federal pelos atos do interventor - Parecer - in Revista de Jurisprudencia Brasileira - Rio de Janeiro - 1928 - vol. II — pagina 415 - C345(81) (05) 1 - 1928 - v. 2.

75. Da transmissão ou cessão das obrigações - Revista de Critica Judiciaria - Rio de Janeiro - 1924 - vol. 1 - pagina 318 - 04-16-2.

76. Despejo injusto - Pagamento de aluguel por consignação judicial - Pena para o senhorío que manda lançar o alugador fóra da casa maliciosamente e sem justa causa - (Parecer) in Revista Forense - Belo Horizonte - 1909 - volume 10 pagina 377 - M2-14-10.

77. Emprestimo hipotecario em moeda extrangeira - (Parecer) — in Revista Forense - Belo Horizonte - 1925 - volume 44 - pagina 417 - M3-14-12.

78. Hipoteca de bens de sociedade civil — É valida a disposição dos estatutos de uma sociedade civil que prescreve poder a assembléia geral extraordinaria deliberar em segunda convocação, qualquer que seja o numero de socios presentes - A assembléia geral póde autorizar a constituição de hipoteca sôbre os bens sociaes - Não se computam os votos dọ socios ausentes - (Parecer) - in Pareceres - Rio de Janeiro 1934 - volume II - pagina 287 - I1-13-2.

79. Hipoteca para liquidação de divida. - Validação do contrato, no caso de simulação innocente - Validade de hipoteca quando constituida fóra do tempo legal da falencia, embora para liquidação de divida anterior - (Parecer) - in Pareceres - Rio de Janeiro - 1933 - volume I - pagina 205 - I1-13-1.

80. Illegitimidade de procurador - Ratificação - Obrigação liquida e certa - Protesto de conta corrente - Requerimento da falencia - (Minuta e contra minuta e agravo) - in Revista do Supremo Tribunal - Rio de Janeiro - 1914 - volume 2 parte 2 - pagina $130 / 143$ - 012-11-4.

81. Locação de cousas - Rendas e danos resultantes - Intelligencia do disposto no § único do artigo 1.193 do Codigo Civil - (Pareceres) - in Memorial da Apelação Civel nu- 
mero 14.196 - São Paulo - 1925 - pagina $22-24$ e 28 S3-24-33.

82. Locação de prédio urbano - Irretroatividade da lei do inquilinato - (Pareceres) - in Revista Forense - Belo Horizonte - 1925 - vol. 4 - pagina 435 - M3.14-12.

83. Locação de serviços - (Pareceres) - in Revista do Supremo Tribunal - Rio de Janeiro - 1923 - volume 48 - pagina 435 - 014-11-21.

84. Mutuo civil com garantia hipotecaria - in Revista Juridica - 1916 - vol. 2 - pagina 447 - R12-22-5.

85. Nulidade de hipoteca - (Pareceres) - in Diario do Povo - Rio de Janeiro - 1920 - vol. 2 - pagina 147 - S6-60-26.

86. Perdas $e$ danos - Atos preparatorios para um contrato definitivo - (Pareceres) - in Revista Forense - Belo Horizonte - 1910 - volume 14 - pagina 391 - M2-14-12.

87. Perdas e interesses por culpa contratual - (Alegações) in Revista Forense - Belo Horizonte - 1916 - volume 25 - pagina 307 - M2-14-23.

88. Predio arrendado por contrato - Deposito de alugueis Efeito - Despejo malicioso e sem justa causa - in Revista de Díreito - Rio de Janeiro - 1909 - volume 13 - pagina 479 N1-17-13.

89. Responsabilidade da União por atos do Interventor - in Pandectas Brasileiras - Rio de Janeiro - 1929 - volume 7 2.a parte - pagina 458 - H1-16-8.

90. Simulação inocente - Irrevogabilidade do mandato que simula, inocentemente um penhor (Parecer) - in Pareceres Rio de Janeiro - 1933 - vol. I - pagina 145 - I1-13-1.

91. Testamento cerrado - Quem pode ser testemunha - in Revista dos Tribunaes - São Paulo - 1916 - volume 21 - pagina 65 - N5-17-21.

\section{Direito Comercial.}

92. Bancos e Casas Bancarias - Caracteristicas e diferenças dos bancos e casas bancarias - (Pareceres) - in Pareceres - Rio de Janeiro - 1934 - vol. II - págína 329 - I1-13-3.

93. Caixas de liquidação - Clausulas licitas nos contratos entre as Caixas de liquidação e os seus clientes - Parecer - in Pareceres - Rio de Janeiro - 1936 - volume III — pagina 57 I1-13-3. 
94. Cessão dos direitos de interventor - Cedidos pelo interventor os seus direitos e obtida a patente, no Brasil, pelo cessionario, ninguém poderá usar, durante o tempo do privilegio, o processo patenteado para a fabricação e venda do produto - in Pareceres - Rio de Janeiro - 1936 - volume III - pagina 400 - I1-13-3.

95. Da validade dos debentures nâo inscritos no livro especial do registro geral de hipotecas (Pareceres) in Revista de Jurisprudencia Brasileira - Rio de Janeiro - 1929 - volume V paginas 193, 199 e 206 - C 345 (81) (05) 11929 - v. 5 .

96. Das fontes do direito comercial brasileiro - in O Direito - Rio de janeiro - 1902 - volume 89 - paginas 5 e 321 - P13-23-15.

97. Das Juntas Comerciaes e do Registro Publico do Comercio in O Direito - Rio de Janeiro - 1905 - volume 96 - pagina 5 - P13-23-22.

98. O direito comercial brasileiro - in Archivo Judiciario - Rio de Janeiro - 1928 - Discurso - vol. 8 - pagina 63 do suplemento - 03-17-8.

99. Direito e legislação sobre melhoramento dos portos nacionaes e servico a cargo das empresas ou companhias e docas - in 0 Direito - Rio de Janeiro - 1902 - volume 87 - pagina 5, 185, 385 e 529 - P13-23-13.

100. O direito de renovação de registro de marcas de fabrica e de comercio em face do direito constituido, da doutrina e da jurisprudencia - Parecer - in Razões de Recurso da Diretoria Geral de Propriedade Industrial - São Paulo - 1929 - pagina 33 - N4-25-27.

101. Discurso agradecendo a homenagem do Instituto da Ordem dos Advogados - O direito comercial no fim do seculo XIX - A sistematização do nosso direito comercial - A recisão das leis comerciaes, e a colaboração indispensavel dos juristas A crise atual da magistratura e da advocacia - Meios para conjurar a crise - in Boletim do Instituto da Ordem dos Advogados Brasileiros - Rio de Janeiro - 1928 - volume IV pagina 36 - Q13-15-5.

102. Dos atos de comercio no direito brasileiro - in O Direito Rio de Janeiro - 1903 - volume 91 - pagina 5, 185 e 333 P13-23-17.

103. Dos agentes de leilōes ou leiloeiros - in O Direito - Rio de Janeiro - 1905 - volume 98 - pagina 5 - P13-23-24.

104. Dos comerciantes - Da disciplina juridica da profissão mercantil - in O Direito - Rio de Janeiro - 
P13-23-18 - 1903 - volume 92 - paginas 5 e 161 -

P13-13-20 - 1904 - volume 94 - paginas 5 e 433.

105. Dos corretores - in O Direito - Rio de Janeiro - 1905 volume 97 - paginas 5 e 149 - P13-23-23.

106. Dos despachantes geraes das alfandegas - in O Direito Rio de Janeiro - 1906 - volume 100 - pagina 5 - P13-23-26.

107. Dos prepostos das casas comerciaes ou dos empregados no comercio - O negocio mercantil em relação ao seu pessoal - in O Direito - Rio de Janeiro - 1906 - volume 99 pagina 5 - P13-23-25.

108. Leiloeiro - Leilão - Vendas Judiciaes - in Gazeta Juridica - São Paulo - 1901 - volume 26 - pagina 199 - R16-23-14.

109. Letra de cambio - Para, em nome de terceiro, aceitar, endossar ou avaliar alguem uma letra de cambio faz-se necessário mandato especial? - in Revista de Comercio e Industria São Paulo, 1917 - vol. 3 - pagina 14 - Q15-20-14.

110. Leiloeiro - Leilão - Vendas Judiciaes - in Gazeta Juridica São Paulo - 1901 - pagina 199 - R16-23-14.

111. Monopolio Industrial - Concessão exclusiva de estabelecimentos modelos para conservação de carne por processos frigorificos - (Pareceres) - in Revista Forense - Belo Horizonte - 1916 - vol. 26 - pagina 417 - M2-14-24.

112. Navegação de pequena cabotagem - Não podem fazer navegação de pequena cabotagem os rebocadores e saveiros de propriedade de extrangeiros e arrolados na Capitania do Porto, para serviços no respectivo porto ou rio navegavel - (Parecer) - in Pareceres - Rio de Janeiro - 1936 — volume III - pagina 135 - 11-13-3.

113. Nota promissória - Numa nota promissoria regularmente emitida e que reveste todos os caracteristicos legaes, o credor em favor do qual foi emitido o titulo, exarou no verso o endosso concebido nos seguintes termos: "Pague-se á ordem de F, valor em conta", datando e assinando em seguida - Pergunta-se: este endosso importa transmissão de propriedade? ou méro mandato de cobrança? - Sendo certo que tanto a inclusão da clausula a ordem, como a de valor em conta, sejam segundo a lei vigente, excusados e inuteis, todavia essas expressões são de molde a desvirtuar o endosso ou deixam duvida sobre a prioridade do titulo? - O endossatario, a quem $o$ titulo foi transferido por essa fórma tem qualidade para, em nome proprio, apresentar-se na fallencia do devedor emissor da promissoria, e ser incluido na relação dos credores do 
fallido? - in Revista de Comercio e Industria - São Paulo, 1916 - vol. 2. - pagina - 325 - Q15-20-13.

114. Qual é a melhor organização do registro do comercio? - in Revista Forense - Belo Horizonte - 1923 - volume 41 pagina 10 - M3-14-9.

115. Penhor do estabelecimento mercantil - in Revista do Supremo Tribunal - Rio de Janeiro - 1921 - volume 28 - pagina 437 - 014-11-1.

116. Pluralidade de Diarios - A lei nạ̃o exige que o Diario, livro obrigatorio dos comerciantes, seja um só - Não é admissivel a escrituração em folhas avulsas, para serem depois encadernadas, formando Diarios auxiliares - (Parecer) - in Pareceres - Rio de Janeiro - 1936 - volume III - pagina 343 - I1-13-3.

117. Prefacio ao "Curso de direito comercial" de Alfredo Russell - in Curso de direito comercial - Rio de Janeiro - 1938 volume 1 - parte I - pagina 5 - K2-14-42.

118. Reclamação reivindicatoria - Reserva de Dominio - in Reclamação reivindicatoria - São Paulo - 1928 - paginas 37 e 45 - S14-20-15.

119. Será util a admissão do penhor do estabelecimento comercial? No caso afirmativo quaes as cautelas a adoptar em garantia de terceiros? - in Revista Forense - Belo Horizonte - 1923 - volume 41 - pagina 12 - M3-14-9.

120. Serviço de inspeção com relação aos produtos sujeitos ao regimen da lei n. 452 de 3 de novembro de 1897 - (Parecer) - in Guia Fiscal — São Paulo, 1926 - ano I - numero 4 pagina 365 - F2-23-2.

121. Transporte de passageiros em ferro-carril urbano - Dano pessoal - Prescrição da ação de indenização - (Parecer) - in Revista Forense - Belo Horizonte - 1927 - volume 48 pagina 352 - M3-14-16.

122. Usos e costumes comerciaes - Os usos e costumes comerciaes das nossas praças em seus varios ramos de atividade comercial - in Revista de Comercio e Industria - 1919 - vol. 5. pagina 234 - Q15-20-16.

\section{Concordata Preventiva.}

123. Compensação - Não se dá compensação no caso de concordata preventiva - (Parecer) - in Pareceres - Rio de Janeiro - 1933 - vol. I - página 201 - I1-13-1. 
124. Não há compensação na concordata preventiva — A concordata preventiva não produz compensação, pois importaria em pagamento antecipado que a lei condena - (Parecer) - in Pareceres - Rio de Janeiro - 1933 - volume I — pagina 341 - I1-31-1.

125. Concordata extra judicial - Embora unanime não vincula os credores entre si - (Parecer) - in Pareceres - Rio de Janeiro - 1933 - volume I - pagina 9 I1-13-1.

126. Concordata preventiva - Contratos celebrados pelo concordatario - Um negociante que celebrou com seus credores uma concordata preventiva, que foi homologada pelo juiz cuja sentença passou em julgado, póde efetuar contratos no giro de seu comercio? - in Revista de Comercio e Industria São Paulo - 1916 - volume 2. — pagina 55 - Q15-20-13.

127. Concordata preventiva - Deve ser havido por confesso o credor impugnado que, na verificação de seus creditos, recusa a exibição dos seus livros - Não homologada a concordata preventiva pelos atos de má fé do devedor e pela inclusão de créditos simulados, no passivo não pode ser admitida outra que ele ofereça na falencia - Homolagada a concordata preventiva, paga as custas quem a embargou - Não homologada, deve pagal-as a massa falida que se forma em consequencia da decisão final - (Parecer) - in Pareceres - Rio de Janeiro - 1933 - volume I - pagina 395 - I1-13-1.

128. Concordata preventiva - Impugnação e credor incluido exibição dos seus livros — Pena de confesso — Quem não póde propor concordata na falencia - Embargos a concordata preventiva - Vencimento - Pagamento das despesas judiciaes -A quem incumbe - (Parecer) - in Revista de Direito - Rio de Janeiro - 1918 - volume 50 - pagina 122 - N1-16-24.

129. Concordata preventiva - Impugnação - Homologação (Parecer) - in Revista dos Tribunaes — São Paulo — 1916 volume 19 - pagina 5 - N5-17-19.

130. Concordata preventiva - Impugnação - Homologação Póde, em face da lei de falencias, ser homologada uma concordata preventiva em que se oferece aos credores sómente o pagamento de $5 \%$ ? - Tendo havido protesto contra a concordata, reafirmada pelos embargos julgados procedentes, estava o juiz obrigado a homologal-a? - in Revista de Comercio e Industria - São Paulo - 1916 - volume 2. - pagina 151 Q15-20-13. 
131. Concordata preventiva - Não póde a maioria conceder prorrogação - (Parecer) - in Parecer - Rio de Janeiro - 1933 - volume I - pagina 13 - I1-13-1.

132. Concordata preventiva - Não póde ser processada a concordata preventiva, e é de declarar a falencia do devedor quando a percentagem oferecida é inferior ao minimo que a lei permite - (Parecer) - in Pareceres - Rio de Janeiro - 1933 - volume I - pagina 223 - I1-13-1.

133. Concordata preventiva - Reclamação reivindicatoria - in Revista de Direito - Rio de Janeiro - 1917 - volume 45 pagina - 38 - N1-16-19.

134. Concordata preventiva - Reclamação reivindicatoria - Inadmissibilidade - Defesa do Credor - (Parecer) - in Revista dos Tribunaes - São Paulo - 1914 - volume 10 - pagina 6 $-\mathrm{N} 5-17-10$.

135. Concordata preventiva - Segundo o art. 157 da lei n. 2.024 de 1908, durante o processo da concordata preventiva, o devedor conservara a administração de seus bens e continuará com o seu negocio sob a fiscalização dos comissários, mas não poderá alienar ou hipotecar os imoveis nem constituir penhores, nem contrair novas obrigações, salvo com autorização expressa do juiz, por evidente utilidade, ouvidos os comissarios - Sendo o devedor uma sociedade em nome coletivo, a proibição fere a capacidade da entidade social sómente ou se estende aos membros solidarios da mesma sociedade? - in Revista de Comercio e Industria - São Paulo - 1918 volume 4 - pagina 187 - Q15-20-15.

136. Concordata preventiva de sociedade - A concordata preventiva das sociedades em nome coletivo e em comandita deve ser requerida com intervenção direta de todos os socios com direito ao uso da firma e em nome da sociedade - (Parecer) - in Pareceres - Rio de Janeiro - 1933 - volume I pagina 147 - I1-13-1.

137. Co-obrigados na concordata preventiva - Como deve ser pago o credor de co-obrigados em concordata preventiva - (Parecer) - in Pareceres - Rio de Janeiro - 1933 - volume I - pagina 429 - I1-13-1.

138. Custas - Remuneração do sindico e do comissário - As custas da concordata preventiva correm por conta de quem as promove - Credor recorrente - Si a falência ficou sem efeito em virtude de provimento de agravo, não houve liquidação e não ha comissões a pagar - in Pareceres - Rio de Janeiro - 1933 - volume I - I1-13-1. 
139. O descendente não póde embargar a concordata preventiva do ascendente - (Pareceres) - in Revista dos Tribunaes São Paulo - 1924 - volume 50 - pagina 318 - N5-16-15.

140. O descendente não póde embargar a concordata preventiva do ascendente - (Pareceres) - in Revista de Direito - Rio de Janeiro - 1924 - volume 72 - pagina 287 - N1-15-20.

141. Mandato conferido ao concordatario antes da concordata preventiva - A concordata preventiva não faz cessar "ipso jure" o mandato anteriormente conferido ao concordatario - A morte de um dos socios não dissolve a sociedade, quando houver clausula de continuação com os sobreviventes - (Pareres) - in Pareceres - Rio de Janeiro - 1933 - volume I - pagina 181 - I1-13-1.

142. Oferecimento de concordata preventiva depois de ajuizada a falencia - Não póde ser admitido o pedido de concordata preventiva, si um credor se antecipa em requerer a falencia (Parecer) - in Pareceres — Rio de Janeiro - 1933 - volume I - pagina 255 - I1-13-1.

143. Pedido de concordata preventiva não determina o vencimento antecipado - A clausula salvo reembolso não tem aplicação antes do vencimento das cambiaes creditadas em conta corrente - Nas relações entre as partes póde ser pesquizada a causa da obrigação cambial - O banqueiro portador de titulos descontados em conta corrente póde tomar parte na concordata preventiva sómente pelo saldo demonstrado nesta conta, no momento do requerimento da concordata - (Parecer) - in Pareceres - Rio de Janeiro - 1933 - volume I — pagina 389 - I1-13-1.

\section{Falência.}

Ação revocatoria e ação de revisão - Semelhanças e diferenças entre a ação revocatoria e ação de revisão - Ação revocatoria e de revisão são independentes uma da outra - Aquela prescreve em um ano, esta não prescreve enquanto não se encerra a falencia - Não produz efeitos em relação a terceiros penhor de todos os bens moveis de um estabelecimento ou empreza judicial - (Pareceres) - in Pareceres - Rio de Janeiro - 1933 - volume I - pagina 359 - I1-13-1.

144. Aceitação de concordata - Não sendo homologada a concordata perde todo o valor a aceitação que lhe foi dada pelos credores, fazendo-se necessaria nova aceitação destes, si houver de ser feita nova proposta - Os procuradores que aceitam concordata devem provar o seu mandato - (Parecer) - in 
Pareceres - Rio de Janeiro - 1933 - volume I — pagina 113 - I1-13-1.

145. Ações contra o socio de sociedade em nome coletivo falidaf nula a ação proposta por credor individual de um socio de sociedade em nome coletivo, no estado de falencia, sem audiencia do sindico - (Parecer) - in Pareceres - Rio de Janeiro - 1933 - volume I — pagina 43 - I1-13-1

146. Não é comerciante o socio de responsabilidade ilimitada de uma sociedade comercial e, pois, não póde dito socio, como particular ou na qualidade de socio solidário, ser diretamente declarado falido por obrigações pessoaes ou pela sociedade de que faz parte - (Parecer) - in O Direito - Rio de Janeiro - 1909 - volume 110 - pagina 10 - P15-23-11.

147. Companhias de seguros - Inadmissibilidade da sua falencia requerida pelo segurado - (Parecer) - in Revista dos Tribunaes - São Paulo - 1927 - volume 64 - pagina 57 - N5-16-29.

148. Companhias de seguros - Inadmissibilidade da falencia della, requerida pelo segurado - (Parecer) - in Revista Forense - B. Horizonte - 1927 - volume 48 - pagina 473 - M3-14-16.

149. Compensação entre o credito do socio comanditario e a sua divida de capital - Compensa-se na falencia da sociedade em comandita simples, o credito do socio comanditario com a sua divida de quota social - $\mathrm{O}$ socio comanditario que é credor da sociedade, fica equiparado aos outros credores e toma parte nas deliberações da assembléia - (Parecer) - in Pareceres - Rio de Janeiro - 1933 - volume I - pagina 355 - I1-13-1.

150. Compra e venda com o pacto "reservati dominii" - Falindo o devedor, qual a posição de terceiros que recebem em penhor os bens, objecto daquela compra e venda, na falencia do devedor - (Parecer) - in Reclamação reivindicatoria - São Paulo - 1928 - pagina 39 e 45 - N3-24-18.

151. Concordata na falencia - Os bens particulares dos socios arrecadados na falencia, não passam para o patrimonio do socio concordatario - (Parecer) - in Pareceres - Rio de Janeiro - 1933 - volume I — pagina 35 - I1-13-1.

152. Concordata - Homologação - Como deve ser proferida a sentença - (Parecer) - in Revista do Direito - Rio de Janeiro - 1911 - volume 22 - pagina 100 - N1-17-22.

153. Concordata - Modificação das bases propostas pelo devedor - in Revista Forense - Belo Horizonte - 1929 - volume 53 - pagina 237 - M3-14-21. 
154. Concordata plara pagamento em ações - O credor na concor. data, não é obrigado a receber outra cousa que não seja dinheiro - Nulidade da concordata formada por sociedade anonima para pagamento em ações emitidas pela propria Companhia - (Parecer) - in Pareceres - Rio de Janeiro - 1933 volume I - pagina 317 - I1-13-1.

155. Concordata - Prestações sem determinação dos respectivos valores - Estipulada uma concordata a prazo, sem determinação do valor das prestações, entende-se que são iguaes ( $\mathrm{Pa}$ recer) - in Pareceres - Rio de Janeiro - 1933 - volume I - pagina 95 - I1-13-1.

156. Concordata com um dos socios - A concordata com um dos socios exonera os outros, sendo-lhes entregues os seus bens particulares - Respondem todavia esses bens, quando a concordata fica sem efeito por falta de pagamento dos credores privilegiados e das despesas da falencia - (Parecer) - in Pareceres - Rio de Janeiro - 1933 - volume I - I1-13-1.

157. Concurso preferencial em falencia entre uma hipoteca regularmente inscripta, outorgada em favor de um emprestimo por debentures não inscripto no livro especial de registro desses emprestimos, e outro emprestimo da mesma natureza regularmente inscripto no mencionado livro, contrahido dez anos depois - Prelação da hipoteca anterior - (Parecer) - in Revista de Direito - Rio de Janeiro - 1913 — volume 30 pagina 459 - N1-16-4.

158. Contrato celebrado pelo falido - Póde o falido contratar para obter recursos para a concordata - (Pareceres) - in Pareceres - Rio de Janeiro - 1933 - volume I - pagina 59 I1-13-1.

159. Co-obrigados - Direito do Portador na falencia do endossante quando o titulo ainda não se acha vencido e o aceitante está "in nobis" - (Parecer) - in Pareceres - Rio de Janeiro 1933 - volume I — paginas 127/131 - I1-13-1.

160. Co-obrigados - Póde o portador da cambial, depois do vencimento ajustar com qualquer dos co-obrigados não falido, o modo de pagamento, contratar garantias receber parcialmente a divida, etc. - (Parecer) - in Pareceres - Rio de Janeiro - 1933 - volume I - pagina 331 - I1-13-1.

161. Credor hipotecario - o credor hipotecario que iniciou a sua ação antes da falencia, fica fóra do concurso, não podendo tomar parte nas deliberações da massa - (Parecer) - in Pareceres - Rio de Janeiro - 1933 - volume I - pagina 251 I1-13-1. 
162. Credor hipotecario na falencia - Direitos do credor hipotecario em face da venda do imovel que lhe serve de garantia (Parecer) - in Pareceres - Rio de Janeiro - 1933 - volume I - pagina 265 - I1-13-1.

163. Credores por despesas com molestias e enterro do falido Classificação dos creditos provenientes de molestia e enterro do falido - (Parecer) - in Pareceres - Rio de Janeiro 1933 - volume I — pagina 259 - I1-13-1.

164. Credito de aluguel, na falencia - Aluguel - Classificação na falencia - A retroatividade da falencia sómente é apreciavel para efeito de invalidade de certos atos - (Parecer) - in Pareceres - Rio de Janeiro - 1933 - volume I pagina 15 - I1-13-1.

165. Credores não habilitados na falencia - Não concorrem na falencia credores que não se habilitaram, alegando e provando o seu efeito - (Parecer) - in Pareceres - Rio de Janeiro 1933 - volume I - pagina 83 - I1-13-1.

166. Culpa no requerimento da falencia - Incorre em culpa o credor que, sem usar da maxima prudencia e cautela, requerer a falencia de um co-obrigado que, intimado de protesto, declara ser falsa a sua firma - (Parecer) - in Pareceres - Rio de Janeiro - 1933 - volume I - pagina 159 - I1-13-1.

167. Da exigibilidade antecipada ou prematura das dividas passivas do falido, seus efeitos, e influencia relativamente ás obrigações condicionaes e solidarias - in O Direito - Rio de Janeiro - 1895 - volume 68 - pagina 161 - P11-23-20.

168. Da falencia das sociedades em liquidação - As sociedades comerciaes dissolvidas por acôrdo dos socios ou por decreto judicial e em liquidação, estão sujeitas á falencia, desde que se caracterize este estado, ainda depois do ato da dissolução (Parecer) - in O Direito — Rio de Janeiro - 1905 - volume 97 - pagina 309 - P13-23-23.

169. Debentures - Falta de recebimento dos juros - Falencia in Revista de Comercio e Industria - São Paulo - 1919 volume 5 - pagina 322 - Q15-20-16.

170. Desistencia de ação promovida pela massa falida - O liquidatario pode desistir da ação que intentar em nome da massa - (Parecer) - in Pareceres - Rio de Janeiro - 1933 volume I - pagina 325 - I1-13-1.

171. Desistencia da falencia - A desistencia do credor que requereu a falencia não determina encerramento desta, quando já houver sido declarada - (Parecer) - in Pareceres - Rio de Janeiro - 1933 - volume I — pagina 63 - I1-13-1. 
172. Direitos que assistem ao comprador, em leilão, de bens cedidos para pagamento dos credores da massa, no caso de o juiz ordenar novo leilão a requerimento de um dos sindicos (Parecer) - in O Direito - Rio de Janeiro - 1901 - volume 85 - pagina 24 - P13-23-11.

173. Do regimem da concordata na falencia - in Revista de Comercio e Industria - São Paulo - 1919 - volume 4. - pagina $10-\mathrm{Q} 15-20-16$.

174. Do saldo do credor hipotecario em face da concordata do devedor - O credor hipotecario pelo saldo é méro chirografario e, em consequencia, está sujeito ao dividendo da concordata - Pouco importa que esse saldo sómente se verificasse depois de homologada a concordata, vista que esta obriga todos os credores admitidos, ou não, á falencia - in Revista de Direito - Rio de Janeiro - 1926 - volume 81 - pagina 330 N1-14-1.

175. Efeitos da concordata em relação aos atos revogados na falencia - A revogação dos atos do falido anteriores á falencia aproveita sómente á massa - Não poderá entretanto, o credor, cuja hipoteca foi revogada, penhorar cordata, ou si se obrigou o concordatario a deles não dispôr antes de cumprida a concordata - (Parecer) - in Pareceres - Rio de Janeiro - 1933 - volume I - pagina 105 - I1-13-1.

176. Efeitos da concordata, quanto aos atos revogados na falencia - A concordata homologada faz perder a razão de ser da revogação de atos praticados pelo falido - Rescindida a concordata, readquire a massa os bens que fazem parte de hipoteca revogada na falencia - (Parecer) - in Pareceres - Rio de Janeiro - 1933 - volume I - pagina 81 - I1-13-1.

177. Efeitos da falencia sobre as escrituras de hipotecas - Si é valida uma hipoteca feita em garantia de debito anterior, ha mais de 40 dias da sentença que decretou a falencia, porém, dentro dos 40 dias do primeiro protesto - in Revista do Supremo Tribunal - Rio de Janeiro - 1921 - volume 29 pagina 377 - 014-11-2.

178. Empresa falida - Penhor da totalidade dos bens - Efeito quanto ao credito - Impugnação - Omissão ou insuficiencia da prova - Remedio - Ação de revisão e ação revocatoria - Tempo para propositura - Seus fins - Prescrição (Parecer) - in Revista de Direito - Rio de Janeiro - 1916 - volume 39 - pagina 227 - N1-16-13

179. Espera concordataria concedida aos bancos nacionaes pelo decreto federal n. 703 de 10 outubro de 1900 - Compensação 
e encontro de contas - in Gazeta Juridica - São Paulo volume 25 - pagina 16 - R16-23-13.

180. Exclusão de credor, depois de pago o seu credito - Execução de sentença que, em ação de revisão manda escluir um credito já pago - (Parecer) - in Pareceres - Rio de Janeiro 1933 - volume I - pagina 381 - I1-13-1.

181. Execução de contratos bilateraes na falencia - Em regra, podem ser transferidos pela massa, independentemente de autorisação, os contratos bilateraes celebrados com o falido - (Parecer) — in Pareceres - Rio de Janeiro - 1933 volume I - pagina 117 - I1-13-1.

182. Exibição de livros dos credores, nos embargos á concordata - No processo de embargos a concordata póde ser ordenada a exibição parcial dos livros dos credores acusados de conluio com o concordatario - Nesse caso de conluio, devem taes credores ser notificados, para que se defendam até devem também ser dirigidos contra eles os embargos - (Parecer) - in Pareceres - Rio de Janeiro - 1933 - volume I pagina 91 - I1-13-1.

183. Falencia - Ação revocatoria - Prazo de um ano - Quando começa a correr - (Parecer) - in Revista dos Tribunaes - São Paulo - 1929 - volume 70 - paginas 9 e 11 - N5-15-5.

184. Falencia do aceitante de cambial, antes do vencimento Não é necessario prévio protesto para que o portador da cambial cujo prazo ainda não expirou possa apresentar-se na falecida do aceitante - (Pareceres) - in Pareceres - Rio de Janeiro - 1933 - volume I - pagina 413 - I1-13-1.

185. Falencia - Clausulas penaes - Multas convencionaes - Creditos da fallencia - Quando tal se verifica - (Pareceres) in Revista de Direito — Rio de Janeiro — 1914 - volume 33 - pagina 435 - N1-16-7.

186. Fallência de Companhia de Seguros requerida por segurado - Inadmissibilidade - Carta de sentença contra comerciante - Como e quando só da ingresso á falencia deste - Nulidade do instrumento de divida - Deve sempre dela conhecer o juizo da falencia - (Parecer) - in Revista de Direito Rio de Janeiro - 1926 - volume 82 - pagina 318 - N1-14-2.

187 Fallência - Compensação - (Parecer) - Apenso do folheto das razões da Brasilianische Bank Fur Deutschland - São Paulo - 1918 - S14-25-32.

188. Falência - Compensação — Póde alegar compensação o credor que, tendo recebido titulos em caução, foí, não obstante clas- 
sificado como chirografado - (Parecer) - in Pareceres Rio de Janeiro - 1933 - volume I - pagina 407 - I1-13-1.

189. Falência - Concordata - Saldo do credito hipotecario (Parecer) - in Revista Forense - Belo Horizonte - 1927 - volume 48 - pagina 78 - M3-14-16.

190. Falência do conjuge separatista antes de concluido o inventário dos bens do casal - Questões de falência do conjuge separatista antes de concluido o inventário dos bens do casal (Parecer) - in Pareceres - Rio de Janeiro - 1933 - volume I - pagina 307 - I1-13-1.

191. Falência - Credor por conta corrente garantida - Compensação - (Pareceres) - in Revista dos Tribunaes - São Paulo - 1918 - volume 26 - pagina 516 - N5-17-26.

192. Falência - Credor por conta corrente garantida - Penhor - Classificação como credor chirografario - Não interposição de recurso - Reivindicação dos titulos apenhados - Direitos do credor - Pagamento por compensação - Embargos admissibilidade na execução - in Revista do Direito - Rio de Janeiro - 1918 - volume 49 - paginas 233, 238 e 241 N1-16-23.

193. Falência - Credores da concordata e que não receberam as suas quotas por falta de reclamação e não serem conhecidos os seus paradeiros - Prescrição das referidas quotas, com fundamento no artigo 445 do Codigo Comercial - Cumprimento da concordata - (Parecer) - in Revista do Supremo Tribunal — Rio de Janeiro - 1915 - volume 5 - pagina 237 - 012-11-8.

194. Falência - Credores extrangeiros - (Parecer) - in Revista dos Tribunaes — São Paulo - 1922 - volume 6 - pagina 344 - N5-16-6.

195. Falência do devedor executado por sentença - Não dá logar a falência a sentença condenatoria que pende de recursos, ainda que autorize execução provisória - (Parecer) - in Pareceres - Rio de Janeiro - 1933 - volume I - pagina 73 I1-13-1.

196. Falência fundada em titulos descontados e estornados - 0 portador de titulos descontados ou creditados em conta-corrente e estornados por falta de pagamento póde requerer a falência do devedor - Conta corrente - particulariza-se pela recíproca concessão de crédito - Clausula salvo embolso - Desconto - (Parecer) - in Pareceres - Rio de Janeiro - 1933 volume I - pagina 141 - I1-13-1. 
197 Falência com fundamento na falta de deposito da importancia. da condenação - Feita citação ao devedor para pagar a im. portancia da condenação ou nomear bens á penhora, e realizada a nomeação de bens suficientes não póde mais o credor. promover a falência - Para que possa requerer a Falência, deve o credor inicialmente, citar o devedor para pagar ou depositar dinheiro, com a cominação da falência - (Parecer) - in Pareceres - Rio de Janeiro - 1933 - vol. I — pagina 247 - I1-13-1.

198. Falência - Impontualidade de pagamentos - Abandono do negocio - Exame nos livros do credor - Desnecessidade de citação do devedor - (Parecer) - in Revista dos Tribunaes - São Paulo, 1914 - volume 9 - pagina 247 - N5-17-9.

199. Falência - Liquidação da massa - (Parecer) - in Revista. dos Tribunaes — São Paulo — 1916 - volume 18 - pagina 303 - N5-17-18.

200. Falência - Liquidação da massa - Tratando-se de sociedade anonima e havendo duas turbas de credores, obrigacionistas (debenturistas) e chirografarios, como se toma a deliberação a que se refere o artigo 124 da lei numero 2024 de 1908 conjunta ou separadamente por classe de credores com interesses diversos? - (Parecer) - in Revista de Direito — Rio de. Janeiro - 1916 - volume 40 - pagina 463 - N1-16-14.

201. Falência - Prazo para impugnação de creditos - in Revista. do Comercio e Industria - São Paulo, 1916 - volume 2 pagina 229 - Q15-20-13.

202. Falência - Protesto do titulo - Seu objeto - Como póde ser feito o da cambial avalisada - (Pareceres) - in Revista. de Direito - Rio de Janeiro - 1923 - volume 70 - pagina 23 - N1-15-18.

203. Falência - Quanto póde ser interposto agravo da sentença que a decreta - Outras questões - (Pareceres) - in Revista. dos Tribunaes - São Paulo - 1926 - volume 57 - paginas 277/291 - N5-16-22.

204. Falência - Reabertura por não cumprimento de concordata - Agravo - Efeito - (Parecer) - in Revista dos Tribunaes. - São Paulo - 1915 - volume 14 - pagina 63 - N5-17-14.

205. Falência requerida por socios, com fundamento em titulos protestados, mas já resgatados - Deve ser denegada a falencia de uma sociedade anonima, requerida por um acionista, com fundamento em titulos vencidos e protestados, mas resgatados - (Parecer) - in Pareceres - Rio de Janeiro - 1933 — volume I — pagina 375 - I1-13-1. 
206. Sobre a Falência de Sociedade Anonima - in Revista do Supremo Tribunal - Rio de Janeiro - 1919 - volume 21 - pagina 167 - 012-11-25.

207. Falência de sociedade anonima - Ação para integralisação de capital social - Competência em juizo, na ação para integralisação do capital de uma sociedade - (Parecer) - in Pareceres - Rio de Janeiro - 1933 - volume I - pagina 351 - I1-13-1.

208. Falência de sociedade anonima extrangeira - A sociedade anonima extrangeira autorisada a funcionar na Republica fica sujeita ás leis do Brasil podendo os acionistas aqui residentes requerer a sua falencia, no caso de perda de tres quartos do capital - Debenturistas dessas sociedades quando podem requerer a falência, no Brasil - in Pareceres - Rio de Janeiro - 1933 - volume I — pagina 239 - I1-13-1.

209. Falência de sociedade anonima - Não existe mais liquidação forçada de sociedade de crédito real, que foi substituida pela falência - Credor não póde promover a liquidação da sociedade, amigavel ou judicialmente - $\mathrm{O}$ fôro competente para a falência da sociedade anonima é o da sua séde - (Parecer) - in Pareceres - Rio de Janeiro - 1934 - volume II -. I1-13-2.

210. Falência de sociedade em comandita por ações - A sociedade em comandita por ações não incorre em falência pelo fato da perda de tres quartos do capital - social - Para requerer a falência do devedor é necessario que o procurador tenha poderes - (Parecer) - in Pareceres - Rio de Janeiro 1933 - volume I - pagina 277 - I1-13-1.

211. Falência do sublocador - Efeitos da falência em relação aos contratos de locação e sublocação - (Parecer) - in Pareceres - Rio de Janeiro - 1933 - volume I - pagina 433 11-13-1.

212. Falência de sucursais ou filiais de estabelecimentos situados fora do Brasil - Credores locaes e credores da matriz (Parecer) - in Revista Forense - Belo Horizonte - 1922 volume 39 - pagina 25 - M3-14-7.

213. Falência do vendedor - Direitos do comprador na falência do vendedor - (Parecer) - in Pareceres - Rio de Janeiro - 1933 - volume I - pagina 271 - I1-13-1.

214. Falência - Verificação e classificação de créditos - Irrevo. gabilidade - (Parecer) - in Revista dos Tribunaes - São Paulo, 1914 - volume 10 - pagina 45 - N5-17-10.

215. Formalidade da sentença homologatória de concordata - Da acta da assembléia de credores não deve nem póde constar a homologação da concordata, porque não há sentença verbal 
- A sentença que homologa a concordata deve ser subsequente ao acordo, não obstante proferida na mesma ocasião da assembléia de credores - (Parecer) - in Pareceres Rio de Janeiro - 1933 - volume I - pagina 161 - I1-13-1.

216. As garantias oferecidas nas concordatas e o numero dos sindicos nas falências - in Revista de Direito - Rio de Janeiro 1909 - volume 13 - pagina 281 - N1-17-13.

217. Garantias, no periodo suspeito da falência - Nulidade das garantias prestadas no periodo da falência, para garantia de divida anterior - São validas, entretanto essas garantias, quando prometidas no mesmo ato da constituição da divida, desde que não seja uma promessa vaga, mas concretizada, especializando bens - (Parecer) - in Pareceres - Rio de Janeiro - 1933 - volume I - pagina 421 - I1-13-1.

218. As garantias para pagamento de credores - Póde ser deferida ou deve ser declarada a falencia do devedor que pede concordata preventiva, sem dizer quaes as garantias que oferece para pagamento dos credores chirografarios? - Qual o recurso a usar-se quando o representante do ministério publico não for convidado para assistir á arrecadação, á avaliação, e o exame dos livros for realizado sem sua assistencia? — in Revista de Comercio e Industria - São Paulo - 1915 volume I - pagina $95-$ Q15-20-12.

219. Impugnação de crédittos - Qualquer que seja a natureza do crédito, escritura publica, instrumento particular, letra de cambio, nóta promissória, etc. póde o titulo ser impugnado na falencia - (Parecer) - in Parecer - Rio de Janeiro 1933 - volume I — pagina 327 - I1-13-1.

220. Inadmissibilidade da concordata para pagamento em mercadorias - Nas concordatas deve o pagamento ser em dinheiro (Parecer) - in Pareceres - Rio de Janeiro - 1933 - volume I - pagina 97 - I-1-13-1.

221. Inalienabilidade dos imoveis particulares dos socios solidarios, antes de cumprida a concordata, preventiva - A proibição de alienar imoveis antes de cumprida a concordata preventiva estende-se aos bens particulares dos socios - Si foram dados determinados imoveis dos socios em hipoteca, para garantia do cumprimento da concordata, entende-se que os outros imóveis desse socio ficaram disponiveis - (Parecer) - in Pareceres - Rio de Janeiro - 1933 - volume I — pagina 287 I1-13-1.

222. Indenização no caso de denegação da falência - Requisitos para a ação de perdas e danos, no caso de denegação da falência - Não cabe indenização quando a falência é denegada pelo fato de não ser comerciante o devedor - (Parecer) - in 
Pareceres - Rio de Janeiro - 1933 - volume I - pagina 135 - I1-13-1.

223. Integralização do capital pelos acionistas - Embora, em rigor, da verificação de crédito não resulte cousa julgada, essa verificação é irrevogavel, salvo nos casos de falsidade, dólo, simulação ou êrro - $\mathrm{O}$ acionista demandado pela massa para integralisar as ações não póde alegar nulidade das operações praticadas pela sociedade, antes da falencia e muito menos pretender modificar a verificação e classificação dos credores - (Parecer) - in Pareceres - Rio de Janeiro - 1933 volume I - pagina 229 - I1-13-1.

224. Liquidação administrativa do credito hipotecário na falência (Parecer) - in Revista Forense - Belo Horizonte - 1916 - volume 25 - pagina 206 - M2-14-23.

225. Mancomunação do falido com outras pessoas para fraudar os credores - A expressão antes da declaração da falência não se refere ao termo legal da quebra - Inteligência do art. 88 n. III da lei n. 859 de 16 de agosto de $1902-171$ n. 8 da lei n. 5.746 de 9 de dezembro - (Parecer) - in Pareceres Rio de Janeiro - 1933 - volume I - pagina 123 - I1-13-1.

226. Multa contratual - Clausula penal nos contratos e pena pecuniaria - Como se distinguem - $\mathrm{Na}$ falência incluem-se as multas contratuaes e excluem-se as penas pecuniarias - (Pareceres) - in Pareceres — Rio de Janeiro - 1933 - volume I - pagina 217 - I1-13-1.

227 Obrigacionistas e empreiteiros, na falencia do devedor - Situação dos obrigacionistas e empreiteiros de obras, na falência do devedor - (Parecer) - in Pareceres - Rio de Janeiro - 1933 - volume I — pagina 215 - I1-13-1.

228. Pagamento dos credores pignoraticios - O credor pignoraticio é pago imediatamente após a venda dos bens empenhados, preferindo aos credores com privilegio geral - (Parecer) - in Pareceres - Rio de Janeiro - 1933 — volume I — pagina 337 - I1-13-1.

229. Partilhas de herança em que é interessado o falido - E nula a partilha em que é interessado o falido quando feita sem intervenção do sindico ou liquidatário - Não se atende para qualquer efeito, a alegação da ignorancia da falencia - (Parecer) - in Pareceres - Rio de Janeiro - 1933 - volume I - pagina 173 - I1-13-1.

230. Penhor comercial de todos os bens da massa falida dentro do termo falência - (direito comercial) — in Revista Juridica - 1920 - vol. 18 - pagina 53 - R12-22-21. 
231. Penhor - Tradição operada posterior e parcialmente - A tradição simbolica - Ação revocatória para rehaver o que pagou a massa falida para resgate do penhor - (Parecer) in Revista Forense - Belo Horizonte - 1922 - volume 38 - pagina 469 - M3-14-6.

232. O problema constitucional da falencia - Exame da questão na doutrina - Impossibilidade de separar na falencia as disposiçöes de fundo de fórma - Estudo do elemento historico da Constituição Federal - A questão nos stados Unidos da America - Na Republica Argentina - Na Suissa - Na Espanha - in O Direito - Rio de Janeiro - 1899 - volume 79 - pagina 5 - P13-23-5.

233. O novo projeto sobre falências - in O Direito - Rio de Janeiro - 1904 - volume 94 - pagina 161 - P-13-23-20.

234. Questões de direito comercial discutidas no pedido de falência da Cia. União C. dos Varejistas - Provado no juizo da falência, com certidão da Inspetoria de Seguros que a agencia foi fechada a 22 de abril, pode o juiz reconhecer nulidade da citação, e portanto, não caracterizada a impontualidade? — Se valida fosse a citação feita a ex-agente para pagar, sob pena de penhora, havendo bens a serem penhorados, póde o credor pedir a falência? - Póde ele pedir a falência sem desistencia prévia dos privilégios, que tem? - in Pandectas Brasileiras - Rio de Janeiro - 1926 - volume 1 - primeira parte pagina 103 - H1-16-1.

235. Recusa de pagamento de dividendos não autoriza o pedido de falencia - Fixado o dividendo pela assembléia geral, investe-se o acionista de um direito de crédito que póde ser exigindo judicialmente, não autorizando porém, o pedido de falencia da Companhia - (Parecer) - in Pareceres - Rio de Janeiro - 1933 - volume I - pagina 417 - I1-13-1.

236. Reforço de garantia no periodo suspeito - $\mathrm{E}$ ineficaz o reforço de garantia real, dentro do periodo suspeito da falencia (Parecer) - in Pareceres - Rio de Janeiro 1933 - volume I - pagina 165 - I1-13-1.

237. O regimem de concordatas na falência - Não poderá propôr concordata, quer preventiva, quer na falencia, o negociante que ha menos de tres anos, impetrara egual favor, não cumprindo o acordo com os seus credores - A concordata preventiva e a sucessiva á falência, são ramos do mesmo tronco a concordata judicial - Em face da disposição imperativa do artigo 104 da lei numero 2.024 de 1908, o negociante que não cumprir no trienio, qualquer concordata, está inhibido de evocar igual favor - in Revista do Supremo Tribunal 
- Rio de Janeiro - 1917 - volume II - pagina 489 012-11-14.

238. Renuncia do credor privilegiado que toma parte na formação da concordata - O credor privilegiado que toma parte na formação da concordata renuncia o privilegio - Si êsse privilegio consiste em caução de titulos, taes titulos só poderão ser exigidos pelo falido depois de passar em julgado a sentença homologatoria da concordata - (Parecer) - in Pareceres - Rio de Janeiro - 1933 - volume I - pagina 101 - I1-13-1.

239. Rescisão de concordata - Recursos da sentença que julga rescindida a concordata - Rescindida a concordata, o liquidatário que funcionava antes da formação desta, volta a exercer suas funções, mas em caracter provisório, até a eleição do outro, não podendo preceder desde logo a venda dos bens - in Pareceres - Rio de Janeiro - 1933 - volume I pagina 371 - I1-13-1.

240. Resgate antecipado de emprestimo por obrigações ao portador - Não é revogavel na falência, o resgate antecipado de emprestimo por obrigações ao portador, quando estiver estipulado esse resgate no caso de venda dos bens especialmente hipotecados e esses bens houverem sido vendidos - (Parecer) -in Pareceres - Rio de Janeiro - 1933 - volume I - pagina 281 - I1-13-1.

241. Restituição de importancias recebidas a mais em relação aos outros credores na constância da concordata - Ação competente contra o credor que recebe mais do que os outros na constancia da concordata - (Parecer) - in Pareceres - Rio de Janeiro - 1933 - volume I - pagina 335 - I1-13-1.

242. Revogação da falência em grau de recurso - As pessôas proibidas de comerciar incorrem em falência, quando transgridem o preceito legal - Como se entende a reposição ao estado anterior por efeito da revogação da falência - (Parecer) in Pareceres - Rio de Janeiro - 1933 - volume I - pagina 47 - I1-13-1.

243. Revogação do mandato outorgado ao falido - o mandato conferido ao falido fica revogado pela falencia e não se restabelece por efeito da concordata - (Parecer) - in Pareceres - Rio de Janeiro - 1933 — volume I — pagina 171 - I1-13-1.

244. Situação do credor particular, classificado como separatista, em face da concordata da sociedade - Cessando a falência da sociedade, cessa simultaneamente a dos socios de responsabilidade ilimitada — Nesse caso, reassumem os credores particulares dos socios o exercicio integral dos seus direitos 
- Situação do credor separatista de um socio de sociedade falida, em face da concordata homologada - (Parecer) - in Pareceres - Rio de Janeiro - 1933 - volume I — pagina 189 - I1-13-1.

245. Situação dos debenturistas na falência - Privilegio dos credores debenturistas - Nas obrigações ordinarias a garantia dos debenturistas, que existe desde o momento da emissão se especializa com a abertura da falência - Recurso do encerramento da falência - (Parecer) - in Pareceres - Rio de Janeiro - 1933 - volume I - pagina 401 - I1-13-1.

246. Sociedade em comandita - Não existem, no direito brasileiro, sociedades em comandita irregulares ou de fato - Findo o prazo do contracto de sociedade em comandita, si esta continúa, sem as formalidades de novo contrato e registro, os comanditarios se tornam solidarios e incorrem na falencia quando decretada e da sociedade - (Pareceres) - in Pareceres - Rio de Janeiro - 1933 - volume I — pagina 25 - I1-13-1.

247 Sociedade em comandita - O socio comanditario não é credor da sociedade pelo capital com que contribuiu - No caso de concordata feita por outro socio ,não póde esse capital ser exigido do concordatario, na forma dos outros créditos (Parecer) - in Pareceres - Rio de Janeiro - 1933 - volume I - pagina 31 - I1-13-1.

248. Socio, ainda que solidario não é comerciante - Não póde o socio ser declarado falido, por inadimplemento de obrigações individuaes - A solidariedade não imprime ao sócio a qualidade de comerciante - (Parecer) - in Pareceres - Rio de Janeiro - 1933 - volume I - pagina 67 - I1-13-1.

249. Titulos emitidos por fóra, para obter a adesão de credor á concordata - Constitue ato ilícito e como tal, nula a emissão de titulos por fóra em favor de credor, para obter o seu apoio á concordata - (Parecer) - in Pareceres - Rio de Janeiro - 1933 - volume I - pagina 109 - I1-13-1.

250. Venda de bens particulares de socio, na falência - Como podem ser vendidos, na falência da sociedade, os imóveis particulares do socio - (Parecer) - in Pareceres - Rio de Janeiro - 1933 - volume I - pagina 167 - I1-13-1.

251. Venda de bens da massa - A venda de bens da massa só póde ser feita por preço certo em dinheiro - $\mathbf{E}$ nula a venda quando o pagamento tenha de ser feito em ações e debentures emitidas pelo comprador numa companhia - (Parecer) in Pareceres - Rio de Janeiro - 1933 - volume I - pagina 345 - I1-13-1. 
252. Venda, na falência, de imovel arrendado - Direitos do locatario, dada a venda do imovel, na falência do locador - Terceiro, quem seja - Constitue onus real sobre o imovel a obrigação assumida pelo locador de fazer respeitar a locação pelo adquirente - (Parecer) - in Pareceres - Rio de Janeiro - 1933 - volume I - pagina 297 - I1-13-1.

253. Verificação de conta para efeito de falência. - A conta mercantilmente extraida dos livros dos comerciantes, nos termos da lei de falências, serve apenas para reabertura desta - A prova feita com a verificação dos livros do credor dispensa a que possa ser colhida nos livros do devedor - Expede-se precatória, quando credor e devedor residem em logares diferentes - 0 juiz competente para a verificação é aquele perante o qual vae ser requerida a falência - Em regra nomeam-se dois peritos e o juiz deve estar presente ao exame - (Parecer) - in Pareceres - Rio de Janeiro - 1933 - volume I - pagina 17 - I1-13-1.

254. Verificação de conta para instruir o requerimento da falência - $\mathrm{O}$ devedor que exibe livros em branco incorre em pena de confesso - (Parecer) - in O Direito - Rio de Janeiro - 1902 — volume 89 - pagina 167 - P13-23-15.

255. Verificação de conta nos livros do credor - É desnecessaria a citação do devedor para verificação da conta nos livros do credor para efeito de falência - (Parecer) - in Parecer Rio de Janeiro - 1933 - volume I — pagina 211 - I1-13-1.

\section{Obrigações Comerciais.}

256. Armazens de deposito - Direitos do depositante para haver as mercadorias depositadas - Excusa do depositario - Disposições legaes a que está sujeito - Falta de matricula Efeitos - (Parecer) - in Revista de Direito - Rio de Janeiro - 1919 - volume 51 - pagina 35 - N1-16-25.

257 Bilhete de loteria é titulo ao portador - o pagamento do premio sorteado deve ser feito ao apresentante, sem que a Companhia lhe possa exigir outra justificativa de habilitação o recebimento, além da exibição do bilhete - Conta-corrente grafica e conta-corrente contractual - Estorno após o encerramento, balanço e pagamento de saldo - (Parecer) - in Revista de Direito - Rio de Janeiro - 1928 - volume 90 — pagina 433 - N1-14-10.

258. Cessão de bens da firma comercial - Gazeta Juridica - São Paulo, — 1901 - vol. 26 - pagina 32 - R16-23-14. 
259. Os cheques circulares - in Revista de Direito - Rio de Janeiro - 1926 - volume 79 - pagina 303 - N1-15-27.

260. Cheque - Não póde o banqueiro exigir recibo, quando passado o cheque ao portador - (Parecer) - in Pareceres Rio de Janeiro - 1936 - volume III — pagina 55 - I1-13-3.

261. Clausulas "cif" e "alongside ship" no contrato de compra e venda - Riscos da mercadoria vendida com as clausulas "cif" e "alongside ship" - (Parecer) - in Pareceres - Rio de Janeiro - 1936 - volume III - pagina 169 - I1-13-3.

262. A clausula "Cif" na compra e venda mercantil - (Pareceres) - in Revista de Direito - Rio de Janeiro - 1923 - volume 70 - paginas, 423,427 e 433 - N1-15-18.

263. A clausula "cif" na compra e venda mercantil - (Pareceres) — in Revista Forense - Belo Horizonte - 1923 - volume 41 - pagina 525 - M3-14-9.

264. Clausula "cif" no contrato de compra e venda - No contrato de compra e venda com a clausula "Cif" a tradição opera-se no momento do embarque - Saque documentado - A prova da diferença de qualidade da mercadoria deve ser feita pelo comprador, no logar do desembarque - (Parecer) - in Pareceres - Rio de Janeiro - 1936 - volume III — pagina 161 - I1-13-3.

265. Compra e venda de cambiais - Contratos nulos e simulados (Parecer) - in Compra e venda de cambiais. — Rio de Janeiro - 1920 - pagina 40 - S10-24-26.

266. Compra e venda celebrada no Brasil - Competencia de fôro para demandar o vendedor extrangeiro que contrata no Brasil, por intermedio de representante - Póde ser feita a citação inicial na pessôa desse representante - (Pareceres) - in Pareceres — Rio de Janeiro - 1936 - volume III — pagina 177 - I1-13-3.

267. Compra e Venda - Direitos do vendedor - A exploração de pedreira é ato de comércio e é comerciante quem a explora - São tambem comerciantes as empresas que exploram a concessão de obras publicas - Optando pela rescisão do contrato, não tem o vendedor direito á indenização - (Parecer) - in Pareceres - Rio de Janeiro - 1936 - volume III pagina 7 - I1-13-3.

268. Compra e Venda - Inexecução do contrato pelo vendedor Açōes do comprador contra o vendedor que não entrega a cousa vendida - Quando começa a móra do vendedor - Inteligencia dos arts. ns. 197 e 202 do codigo comercial - (Pareceres) - in Pareceres - Rio de Janeiro - 1936 - volume III pagina 157 - I1-13-3. 
269. Compra e venda de maquinas sujeitas a experiencias - A compra e venda de maquinas sujeitas a experiencias constitue negocio juridico sob condição suspensiva - A venda nesse caso, torna-se ineficaz si as experiencias demonstram que as maquinas não se acham nas condições estabelecidas no contrato - (Pareceres) - in Pareceres - Rio de Janeiro 1936 - volume III — pagina 351 - I1-13-3.

257 Compra e Venda de mercadorias depositadas nos armazens geraes - As empresas de armazens geraes não incidem nas disposições do regulamento de selo sobre vendas mercantis - essas emprezas não pódem exigir nem fiscalizar a selagem das vendas á vista dos recibos de deposito e dos conhecimentos de deposito unidos ao "warrant" - (Parecer) - in Pareceres — Rio de Janeiro - 1936 - volume III — pagina 339 I1-13-3.

271. Compra e venda mercantil dependente de prestação de garantia bancaria - Transferencia do contrato pelo estipulante comprador pendente a condição - in Revista de Direito Rio de Janeiro - 1920 - volume 55 - paginas, 261, 266 e 277 - N1-15-2.

272. Compra e venda mercantil, sem estipulação de prazo para entrega - Na compra e venda sem estipulação de praso para entrega, esta deve ser imediata, salvo si das condições do negócio se inferir que deva ser entregue no futuro - Móra presupõe culpa - (Parecer) - in Pareceres - Rio de Janeiro - 1936 - volume III - pagina 45 - I1-13-3.

273. Compra e venda - Nulidade do contrato de compra e venda em que o preço fica ao arbitrio de qualquer das partes (Parecer) - in Pareceres - Rio de Janeiro - 1936 - volume III — pagina 65 - I1-13-3.

274. Compra e venda a tipo convencionado - Na compra e venda a tipo convencionado basta que a mercadoria se aproxime do tipo - (Parecer) - in Pareceres - Rio de Janeiro - 1936 volume III - pagina 143 - I1-13-3.

275. Compra e Venda para entrega na praça - Si a venda foi efetuada para entrega na praça em que são estabelecidos comprador e vendedor, não se exonera este da sua obrigação, entregando no ultimo dia do prazo, documentos comprobatorios de que a mercadoria se acha em viagem - A clausula "cif" só se dá nas vendas de mercadorias a serem transportadas de uma para outra praça - (Parecer) - in Pareceres - Rio de Janeiro - 1936 - volume III — pagina 327 - I1-13-3. 
276. Conhecimento de deposito e "warrant" - Não pódem os armazens geraes entregar parte e conservar outra parte de mercadorias sobre as quaes expediu conhecimento de deposito e "warrant" - (Parecer) - in Pareceres - Rio de Janeiro 1936 - volume III - pagina 221 - I1-13-3.

277 Conta corrente - Clausula salvo embolso - As remessas em conta corrente, de letras de cambio, embora se não estipule expressamente, têm carater condicional e os lançamentos são feitos sob a clausula salvo embolso - (Parecer) - in Pareceres - Rio de Janeiro - 1936 - volume III — pagina 61 - I1-13-3.

278. Conta corrente juridica e conta corrente de calculo - Conta corrente propriamente dita e conta corrente de calculo Carater de remessas - (Parecer) - in Pareceres - Rio de Janeiro - 1936 - volume III - pagina 21 - I1-13-3.

279. Contrato de cambio a prazo superior a noventa dias - Sellos - (Parecer) - in Relatorio da Associação Bancaria - Rio de Janeiro - 1926 - pagina 90 - 13-21-28.

280. Contrato de comissão (Parecer) - in Revista Forense - Belo Horizonte - 1915 - volume 24 - pagina 27 - M2-14-22.

281. Contrato de conta corrente de abertura de credito em conta corrente - Fusão - Pluralidade de correntistas - Natureza da obrigação pelo saldo apurado - Indivisibilidade da conta corrente - (Pareceres) - in Revista Forense - Belo Horizonte - 1922 - volume 39 - pagina 344 - M3-14-7.

282. Ha conveniencia na admissão de ações preferenciaes, atendendo á nossa legislação sobre obrigação ao portador (debentures?) - in Revista Forense - Belo Horizonte - 1923 volume 41 - pagina 11 - M3-14-9.

283. Corretores Livres - Direito de corretor livre á comissão (Parecer) in Pareceres - Rio de Janeiro - 1936 - volume III - pagina 49 - I1-13-3.

284. Das obrigações, dos contratos e da prescripção em materia comercial - in Tratado de Direito Comercial Brasileiro Rio de Janeiro $-1934-2 .^{a}$ ed. volume VI 3 tomos 06-13-12 a 14.

285. Debentures emittidas fóra do paiz - Leis que regem a emissão de debentures no exterior, com a garantia hipotecaria de bens situados no paiz - Trustees, no direito inglez - Excesso de mandato da diretoria (Pareceres) - in Pareceres - Rio de Janeiro - 1934 - volume II - pagina 173 - I1-13-2.

286. Deposito irregular em moeda extrangeira - Como deve ser restituido o deposito irregular bancario em moeda extrangeira 
(Parecer) - in Pareceres - Rio de Janeiro - 1936 - volume III - pagina 139 - I1-13-3.

287. Depositos em armazens geraes - indispensável para que exista a expedição de recibo, ou conhecimento de deposito, desde que o armazem não expediu os recibos ou conhecimento de depósito, mas simples aviso de entrada, as relaçōes juridicas não se regem pela lei n. 1.102 de 1903 e sim pelas disposições do codigo comercial sobre mandato - Nesse caso, não cabe ação de deposito contra o armazem - (Parecer) in Pareceres Rio de Janeiro - 1936 - volume III - pagina 223 - I1-13-3.

288. Deve-se manter a faculdade discrecionaria e sem recurso conferida á Camara sindical dos corretores de fundos publicos para apreciar a legalidade e regularidade dos titulos, $e$, firmada no seu criterio individual, admiti-los ou não a cotação da Bolsa Oficial? - A responsabilidade civil dessas Camaras (decreto n. 2475 de 13 de março de 1897, art. 89) exige essa suprema atribuição que se lhes deu? - in Revista Forense - Belo Horizonte - 1923 - volume 41 - pagina 8 - M3-14.9.

289. Emissão de debentures de companhia nacional no extrangeiro - Limite da emissão de debentures, quando o emprestimo é em moeda metalica susceptivel de oscilação cambial - Lei que rege colocação de emprestimo em praças extrangeiras - (Parecer) - in Pareceres - Rio de Janeiro - 1936 volume III - pagina 289 - I1-13-3.

290. Emissão de debentures de companhia brasileira fora do paizLei que rege o emprestimo por debentures contrahido fóra do paiz - Falta de inscrição - Trustees - (Parecer) - in Pareceres - Rio de Janeiro - 1934 - volume II — pagina 163 - I1-13-2.

291. Emissão de debentures - Pagamento dos respectivos juros Remédio á impontualidade da sociedade emissora - (Parecer) - in Revista Forense - Belo Horizonte - 1919 - volume 32 - pagina 42 - M2-14-31.

292. Emprestimos successivos em obrigações ao portador - Prioridade entre emprestimos successivos em obrigações ao portador - (Parecer) - in Pareceres - Rio de Janeiro - 1934 - volume II — pagina 171 - I1-13-2.

293. Empreza - Trabalhadores - Contrato para fornecimento de mercadoria - Garantia - Inexecução - Impossibilidade temporaria - Efeitos - Culpa - Perdas e danos - Indenização - Criterio - (Pareceres) - in Revista de Direito Rio de Janeiro 1920 - volume 55 - pagina 46 - N1-15-2.

294. Fiança dos corretores - As apolices da divida publica federal, quando oferecidas como fiança dos corretores, devem ser rece- 
bidas pelo valor nominal - (Parecer) - in Pareceres - Rio de Janeiro - 1936 - volume III — pagina 277 - I1-13-3.

295. Fusão das contas correntes de dois devedores - Em que consiste a indivisibilidade da obrigação - (Parecer) - in Pareceres - Rio de Janeiro - 1936 - volume III - pagina 211 - I1-13-3.

296. Inadimplemento de contrato de compra e venda de cambial - Como se liquidam as perdas e danos no caso de inadimplemento, por parte do vendedor, do contrato de compra e venda - (Parecer) - in Pareceres - Rio de Janeiro - 1936 - volume III — pagina 207 - I1-13-3.

297. Inadmissibilidade do "trust" e de sua modalidade o "equipment trust", no direito brasileiro - O direito brasileiro não adopta, mas antes condena, o instituto de "trust" e sua modalidade o "equipment trust" - (Parecer) - in Pareceres - Rio de Janeiro - 1936 - volume III - pagina 203 - I1-13-3.

298. Incendio de mercadorias warrantadas - Quando, no caso de incendio do armazem onde se acham as mercadorias warrantadas está obrigado o portador do "warrant" a a interpor protesto a que se refere o art. 23 da lei n. 1102 , de 21 de novembro de 1903 - o perecimento da mercadoria warrantada não justifica a falta de pagamento da divida - in Pareceres Rio de Janeiro - 1936 - volume III - pagina 267 - I1-13-3.

299. Inscrição do emprestimo em debentures - Onde deve ser feita a inscrição do emprestimo em debentures - Inscrição de hipoteca sobre imoveis, em garantia desse emprestimo (Parecer) - in Pareceres - Rio de Janeiro - 1936 - volumes III — pagina 267 - I1-13-3.

300. "A lei do inquilinato" não se aplica aos "contratos escritos" celebrados na vigencia do Codigo Civil - (Pareceres) - in Revista dos Tribunaes - São Paulo - 1925 - volume 54 pagina 105 - N5-16-19.

301. Liquidação por diferença - Elementos essenciaes do contrato diferencial - Questões de liquidação por diferença - (Parecer) - in Pareceres - Rio de Janeiro - 1936 - volume III - pagina 195 - I1-13-3.

302. Mandatario, necessidade de poderes especiaes para aceitar letras - Para validade do mandato, deve o mandatario ter poderes especiaes - Nos poderes outorgados ao mandatario para fazer e assinar papeis de debito e credito, promover e assinar o que for preciso, são os de mandato geral, não se compreendem os de sacar, endossar, aceitar ou avalizar letras de cambio e notas promissórias - (Parecer) - in Pareceres 
- Rio de Janeiro - 1936 - volume III - pagina 179 I1-13-3.

303. Mandato e comissão - Agente, o que seja, na linguagem technica do comercio - o mandatario póde executar o mandato no proprio nome - $\mathrm{Na}$ comissão mercantil o comissario não é agente - comissão "del credere", em que consiste (Parecer) - in Pareceres — Rio de Janeiro - 1936 - volume III - pagina 309 - I1-13-3.

304. Mandato - Os poderes geraes do art. 145 do codigo comercial não compreendem os de emitir, aceitar ou avaliar letras de cambio - (Pareceres) - in Pareceres - Rio de Janeiro 1936 - volume III — pagina 115 - I1-13-3.

305. Mercadorias warrantadas - Incendio - Protesto - (Parecer) - in Revista de Direito - Rio de Janeiro - 1922 - volume 63 - pagina 78 - N15-1-11.

306. Mudança de estado do comprador, antes da entrega da cousa vendida - O pedido de concordata preventiva do comprador não resolve o contrato de compra e venda, desde que ele prove que dispunha de recursos para pagar o preço, não obstante a concordata - (Parecer) - in Pareceres - Rio de Janeiro - 1936 - volume III — pagina 297 - I1-13-3.

307. Natureza civil ou comercial do penhor - E civil o penhor que garante obrigação originariamente civil, ainda que expressa em titulo mercantil por força da lei, como é a cambial - Sómente ao comerciante impoz a lei a obrigação de arrumar livros com formalidades internas e externas especiaes (Parecer) - in Pareceres - Rio de Janeiro - 1936 - volume III - pagina 381 - I1-13-3.

308. Nulidade dos contratos de cambiaes ou moeda metalica á vista ou á prazo que não tenham pago o selo legal - Operações ficticias de cambio; jogos de bolsa - A excepção de jogo oposta á reclamação de quem perdeu em operações fictícias de cambio, das quaes não se pagou o selo legal — A repetição nos jogos de bolsa proibidos - Liquidação por diferenças nas operações cambiaes a prazo - in Revista Juridica - Porto Alegre - 1900 - volume 4 - paginas 397, 419 e 431 - S14-24-13.

309. As operações a termo e as caixas de liquidação - A posição juridica dos compradores, nos contratos á termo, em face da falência da Caixa de Liquidação - Como se apuram as responsabilidades de cada um e como devem proceder os interessados - A natureza dos depositos e margens para garantia dos contratos - (Parecer) - in Revista de Direito - Rio de Janeiro - 1928 - volume 90 - pagina 420 - N1-14-10. 
310. Pagamento de sobrestadias - Paga sobreestadias aquele por cuja culpa o navio é demorado - Está isento de responsabilidade o recebedor, por conta de quem correm as sobrestadias; si deixou retirar a carga, no prazo da estadia, em virtude da lentidão ou inação dos outros carregadores que tinham carga sobreposta - (Parecer) - in Pareceres - Rio de Janeiro - 1936 - volume III - pagina 27 - I1-13-3.

311. Penas pecuniarias e clausulas penaes nos contratos - As penas pecuniarias, que o n. 4 do paragrafo unico do art. $24 \mathrm{da}$ lei n. 2024 declara não poderem ser reclamadas na falencia, são as multas contratuaes ou clausulas penaes convencionadas pelas partes? - De acordo com o art. 26, paragrafo $3^{\circ}$., as clausulas penaes dos contratos unilateraes á prazo, vencidos e exigiveis antes da falência, devem ser atendidas? - in Revista de Comercio e Industria — São Paulo - 1916 — volume 2. - pagina 17 - Q15-20-13.

312. Penhor mercantil sobre mercadorias do estabelecimento Penhor mercantil independe de transcrição no registro de titulos e documentos - Não póde o comerciante dar em penhor mercadorias do seu estabelecimento, embora descriminando-as e pondo-as á disposição do credor - (Parecer) - in Pareceres — Rio de Janeiro — 1933 - volume I - pagina 155 I1-13-1.

313. Penhor mercantil de titulos - Penhor mercantil e penhor civil regem-se por disciplinas diferentes - Os contratos mercantis não dependem de transcrições no registro de titulos, para validade contra terceiros - As apolices federaes são imperdoaveis, digo, impenhoraveis, salvo nos casos que a lei estabelece - (Parecer) - in Pareceres - Rio de Janeiro - 1936 - volume III — pagina 147 - I1-13-3.

314. Penhor do negocio comercial - Fundo de comercio - (Parecer) - in Revista Forense - Belo Horizonte - 1905 volume III - pagina 378 - M2-14-2.

315. Penhor - A posse do credor é requisito essencial para a existencia do direito real do penhor - A tradição porém, póde ser realizada depois do contrato - (Parecer) - in Pareceres Rio de Janeiro - 1936 - volume III - pagina 239 - I1-13-3.

316. Perecimento de mercadorias warrantadas - Incendiado o armazem onde se achavam as mercadorias warrantadas, o portador do "warrant" está obrigado a interpor o protesto a que se refere o art. 23 da lei n. 1.102 de 21 de novembro de. 1903, se não for pago no dia do vencimento? - (Parecer) - in Revista Forense - Belo Horizonte - 1922 - volume 38 -pagina 142 - M3-14-6. 
317. Portadores de letras hipotecarias - Garantias dos portadores de letras hipotecarias - Não é possivel o contrato coletivo com os portadores de letras hipotecarias - (Parecer) - in (Pareceres - Rio de Janeiro - 1934 - volume II — pagina 37 - I1-13-3.

318. Questões de compra e venda - o comprador que recebe lotes de uma partida vendida está obrigado a pagar o preço do quanto lhe foi entregue e, não o fazendo, póde o vendedor deixar de entregar o resto da partida - O direito de retenção não se exerce fóra dos termos legaes ou do concurso de certas condições de fato. - (Parecer) - in Pareceres - Rio de Janeiro - 1936 - volume III — pagina 187 - I1-13-3.

319. Recibos de deposito dos armazens geraes - Os recibos de armazens geraes não são transferiveis por endosso - (Parecer) — in Pareceres - Rio de Janeiro - 1936 - volume III pagina 37 - 11-13-3.

320. O regime das obrigaçôes ao portador, emitidas pelas sociedades anonimas e comanditarias por ações constantes da lei n. $177 \mathrm{~A}$, de 15 de setembro de 1893, precisa refórmas? Quaes? - in Revista Forense - Belo Horizonte - 1923 - volume 41 pagina 13 - M3-14-9.

321. A reserva de dominio nas duplicatas de vendas mercantís in Revista de Jurisprudencia Brasileira - Rio de Janeiro 1932 - Pareceres — vol. XIV - pags. 7, 12, 13 e 16 - C345 (81) (05) 1 - 1932 - v. 14.

322. Responsabilidade do comissario na compra e venda - O comissario é responsavel pelo terceiro com quem contracta, quer tenha declarado o nome do comitente, quer não (Parecer) in Pareceres - Rio de Janeiro - 1936 - volume III — pagina 315 - I1-13-3.

323. Responsabilidade das Companhia de Estrada de Ferro pelos incendios ocorridos em seus armazens - (Parecer) - in $\mathrm{Pa}$ receres - Rio de Janeiro - 1936 - volume III — pagina 319 - I1-13-3.

324. Responsabilidade do mandatario que não cumpre as instruções do mandante - Responde por perdas e danos o mandatario que não cumprir as instruções do mandante - (Parecer) - in Pareceres - Rio de Janeiro - 1936 - volume III pagina 363 - I1-13-3.

325. Responsabilidade do socio que assume a responsabilidade do passivo social - (Parecer) - in Pareceres - Rio de Janeiro - 1936 - volume III — pagina 117 - I1-13-3.

326. Revogabilidade do mandato - O mandato, ainda que ajustado por tempo certo, é sempre revogavel, salvo clausula expressa 
de irrevogabilidade - Si porém, não houver justa causa para revogação, terá o mandatario direito a indenização - Constituem justa causa para revogação do mandato ter o mandatario feito despeząs não autorizadas nem justificadas, deixar de cumprir as instruções do mandante e o fato de exercer tambem as funções de mandatario de concorrentes mandantes - (Parecer) - in Pareceres - Rio de Janeiro - 1936 volume III - pagina 191 - I1-13-3.

327. Riscos de mercadorias vendidas a termo e entregues à Caixa de Liquidação - Os riscos de mercadorias entregues à Caixa de Liquidação quanđo os não assume o segurador, motins, rebeliōes, revoluções, devem ser em juizo arbitral distribuidos entre a Caixa, o vendedor e o comprador - (Parecer) - in Pareceres - Rio de Janeiro - 1936 - volume III — pagina 281 - I1-13-3.

328. Seguro duplo - ' valida a clausula da apolice que isenta de responsabilidade o segurador se o segurado faz novo seguro da mesma causa, sem expressa permissão daquele - (Parecer) - in Pareceres - Rio de Janeiro - 1936 - volume III pagina 373 - I1-13-3.

329. Transferencia do saldo de um correntista para a conta de outro - Ao comerciante não é licito transferir arbitrariamente os saldos liquidos de um freguez para conta de outro - A ratificação de um ato não importa em autorização para atos identicos, no futuro - (Parecer) - in Pareceres - Rio de Janeiro 1936 - volume III - pagina 15 - I1-13-3.

330. Valor da cousa segurada - Indenização devida pelo segurador, na apolice é dado valor ao objeto do seguro - (Parecer) - in Pareceres - Rio de Janeiro - 1936 - volume III pagina 231 - I1-13-3.

331. Valor da indenização devida pelo segurador — A indenização devida pelo segurador deve equivaler á perda realmente sofrida pelo segurado, até o valor declarado na apolice - Êsse valor é o preço da aquisição, acrescido das necessarias despezas - A depreciação em certa percentagem atribuida a todo o ativo comerciante, para os efeitos de uma concordata preventiva não operam nas relações decorrentes do seguro das mercadorias do concordatario - (Parecer) - in Pareceres - Rio de Janeiro - 1936 - volume III — pagina 105 I1-13-3.

332. Vendas das mercadorias dadas em penhor - Não póde o devedor que, no contrato, havia autorizado o credor a vender a mercadoria, na falta de pagamento, revogar ou restringir, depois essa autorização, sem expresso consentimento do credor 
- (Parecer) - in Pareceres - Rio de Janeiro - 1936 volume III - pagina 367 - I1-13-3.

333. "Warrants" - in O Direito - Rio de Janeiro P13-23-3 - 1898 - volume 77 - paginas 5, 160 e 321 P13-23-7 - 1900 - volume 81 - pagina 5.

333. "Warrants" - in O Direito - Rio de Janeiro vol. 81 - pagina 161 - P13-23-7.

\section{Sociedades Anônimas.}

335. Acionistas sob patrio poder - A representação ou assistencia dos menores, nas assembléias das sociedades anonimas não é mandato - Não se aplica a esses casos a disposição dos estatutos que limita o numero de votos do acionista, como tal e como mandatário - (Parecer) - in Pareceres - Rio de Janeiro - 1934 - volume II — pagina 265 - I1-13-2.

336. Ações gravadas com fideicomisso ou usofruto - Aumento do capital com o fundo de reserva - Usufruto e fideicomisso de ações de sociedade anonima - Aumento do capital com importancias retiradas do fundo de reserva - (Parecer) in Pareceres - Rio de Janeiro - 1934 - volume II — pagina 317 - I1-13-2.

337 Alteração de estatutos de sociedade anonima - Não pédem os estatutos alterar as prescrições dos arts. 131 e 132 do dc. n. 434 de 1891, diminuindo ou aumentando o "quorum" legal, ou impondo maioria mais forte do que a metade mais um dos acionistas presentes - (Parecer) - in Pareceres - Rio de Janeiro - 1934 - volume II — pagina 389 - I1-13-2.

338. Aumento de capital de sociedade anonima - Aumento do capital de sociedade anonima pela incorporação do fundo de reserva e outros disponiveis - (Parecer) - in Pareceres Rio de Janeiro - 1934 - volume II — pagina 303 - I1-13-2.

339. Aumento de capital de sociedades anonimas extrangeiras $\mathrm{O}$ aumento do capital das sociedades anonimas extrangeiras autorizadas a funcionar no Brasil deve observar as leis do paiz de origem - O aumento de capital é modificado dos estatutos, exigindo nova autorização para a sociedade continuar a funcionar na Republica - Autorizada a continuação devem os novos estatutos ser arquivados na Junta Comercial (Parecer) - in Pareceres - Rio de Janeiro - 1934 - volume II - pagina 361 - I1-13-2.

340. Os bens imoveis com que o associado entra para constituição do capital das sociedades anonimas, não estão sujeitos ao pagamento do imposto de transmissão inter-vivos - in Arquivo 
Judiciário - Rio de Janeiro - 1929 - (Parecer) - vol. 9. pagina 93 do suplemento - 03-17-9.

341. Caução de prepostos de sociedade anonima - As ações da propria companhia não pódem servir de caução dos seus prepostos - (Parecer) - in Pareceres - Rio de Janeiro - 1934 - volume II - pagina 337 - I1-13-2.

342. Contrato celebrado pelo administrador da sociedade anonima que a representa perante terceiros brado pelo administrador de uma sociedade anonima que a representa perante terceiros, embora não exista ata da deliberação tomada com os outros administradores - Não responde a sociedade pelo excesso, mas responde pelo abuso de poderes do administrador - (Parecer) - in Pareceres - Rio de Janeiro - 1934 - volume II — pagina 93 - I1-13-2.

343. Conversão das ações ao portador em ações nominativas pela assembléia geral da sociedade anonima, modificando os estatutos (Pareceres) - in Revista dos Tribunaes - São Paulo 1928 - volume 66 - pagina 279 - N5-15-1.

344. Convocação da assembléia por acionistas de sociedade anonima - É nulla a assembléia geral convocada por acionistas sem a prova de que foi apresentado o pedido de convocação aos administradores e estes deixaram de atendel-o dentro do prazo de 8 dias - igualmente nula a convocação por acionistas, quando a assembléia já havia siđo convocada pelos administradores, embora depois daquele prazo - (Parecer) - in Pareceres - Rio de Janeiro - 1934 - volume II pagina 201 - I1-13-2.

345. Dos poderes das assembléias geraes extraordinarias, nas sociedades anonimas - (Pareceres) - in Memorial de ação declaratoria - Rio de Janeiro - 1928 - paginas 55, 67 e 103 S3-25-35.

346. Encampação de uma sociedade anonima - transmissão de imoveis, na encampação de uma sociedade anonima por outra - Quando a encampação depende de aprovação do govêrno (Parecer) - in Pareceres - Rio de Janeiro - 1934 - volume II - pagina 383 - I1-13-2.

347. Entrada de bens para constituição de sociedade anonima. Póde o capital de uma Sociedade Anonima ser, na sua totalidade, subscrito em cousas, bens e direitos. - E dispensavel o deposito prévio de $10 \%$ quando o capital não é realizado em dinheiro - Intervalo entre a assembléia que nomêia louvados para avaliação de bens e a que aprova o laudo - Não é indispensavel que a avaliação seja feita "in loco" - A avaliação, uma vez feita é inatacavel, mas os louvados serão 
responsaveis civìimente $-\mathrm{O}$ ađministrađor não pôđe tomar parte em deliberação em que tenha interesse oppasto - Que se entenđe por interesse oposto? - (Parecer) - in Pareceres - Rio de Janeiro - 1934 - volume II — pagina 105 - I1-13-2.

348. Gratificaçâa extraordinaria aos administradores de sociedade anonima - Póde a assembléia geral de uma companhia arbitrar gratificação extraorđinária aos administradores salvo si os estatutos tratam especialmente da remuneração desses administradores - (Parecer) - in Pareceres - Rio de Janeîro - 1934 - volume II - pagina 339' - 11-13-2.

349. Hipoteca de bens de sociedade anonima - Não pódem os administradores de sociedade anonima, sem expressa autorização dos estatutos ou da assembIéia, hipotecar bens sociaes ainda quanđo para garantia đo preço da acquisição desses bens (Parecer) - in Pareceres - Rio de Janeiro - 1934 - volume II - pagina 56 - II-13-2.

350. Iguatdade dos acionistas de uma sociedade anonima - nulla a clausula đos estatutos que đá a um Estađo da Federação, pelo fato de ser o maior acionista o direito de nomear e destituir um diretor - Os estatutos devem manter os acionistas em pé de igualdade, salvo a poder juridico dos votos - (Parecer) - in Pareceres - Rio đe Janeiro - I934 - volume II - pagina 211 - I1-13-2.

351. Integralização do capital de sociedade anonima com os proprios bens desta - Não póde o capital de uma sociedade anonima ser integralizzado com os proprios bens desta, embóra distribuidos a titulo de bonifícação - (Parecer) - in Pareceres - Rio de Janeiro - 1934 - volume II - pagina 159 - I1-13-2.

352. Irregularidade quanto aos atos institucionaes de sociedade anonima - A falta de publicação no Diario Oficial, dos nomes, profíssōes e morađas đos primeiros administradores não constitue nulíđade da sociedade aronimma - Mođo đe sanar a irregularidade que começou a funcionar antes de arquivar no registro de hipotecas o Diario OfíciaI que publiccou os documentos legaes da sua constituição - (Parecer) - in Pareceres - Rio de Janeira - 1934 - volume II - pagina 145 - I1-13-2.

353. Procuraçốes passadas pelos comerciantes e sociedades anonimas, não precisam ser do proprio punho - (Parecer) - in Revista de Direito - Rio de Janeiro - 1926 - vol. 79 pagina 570 - N1-15-27.

354. Proibiçâao de adquirirem as sociedades anonimas as proprias ą̧ões - îlegal, criminoso e nullo o ato pelo qual o diretor de uma sociedade anonima adquire para esta, as próprias 
ações - Nem a diretoria, nem a assembléia geral pódem autorizar a revenda desses titulos - Meio de sanar a irregularidade - (Parecer) - in Pareceres - Rio de Janeiro - 1934 - volume II — pagina 101 - I1-13-2.

355. Promessa de constituição de sociedade anonima (Parecer) - in Revista Forense - Belo Horizonte - 1928 - volume 50 - pagina 46 - M3-14-18.

356. "Quorum" para deliberar sobre emprestimo por obrigações ao portador - Não comparecendo o "quoreum" de 3/4 para deliberar sübre a emissão de debentures, póde esta deliberar na terceira reunião convocada, qualquer que seja o numero de acionistas presentes - Como deve ser aceito pela assembléia o acordo proposto pelos debenturistas á sociedade anonima - (Parecer) - in Pareceres - Rio de Janeiro - 1934 - volume II — pagina 205 - I1-13-2.

357 "Quorum" para deliberar, sobre fusão, as sociedades anonimas - A fusão constitue modificação dos estatutos da sociedade anonima - Os estatutos pódem ser mais rigorosos na fixação do "quorum" para determinadas deliberaçōes lei das sociedades anonimas tem, em grande dose, carater méramente dispositivo, podendo ser derrogada pelos estatutos - Quaes os preceitos dessa lei que tem carater imperativo? - (Parecer) - in Pareceres - Rio de Janeiro - 1934 - volume III - pagina 263 - I1-13-3.

358. "Quorum" para funcionamento da assembléia geral de uma sociedade anonima - Os estatutos pódem modificar o regimen legal para o funcionamento da assembléia geral de uma sociedade anonima desde que não restrinja os prazos minimos o "quorum" estabelecido e não altere o processo da convocação - (Parecer) - in Pareceres - Rio de Janeiro - 1936 — volume III - pagina 263 - I1-13-3.

359. Redução do capital de sociedade anonima seguido de aumento - Não ha motivo para vedar que, em uma só deliberação, a sociedade anonima reduza o seu capital e em seguida o aumente - (Parecer) - in Pareceres - Rio de Janeiro - 1934 volume II — pagina 261 - I1-13-2.

360. Remuneração aos diretores de sociedade anonima calculada sobre o dividendo a distribuir - A remuneração consistente em percentagem sobre o dividendo distribuido não compreende os lucros acumulados, enquanto permanecerem no fundo social, mas em qualquer tempo em que esses lucros sejam distribuidos, a qualquer titulo, têm os diretores que serviam ao tempo em que se fêz acumulação o direito de reclamar a percentagem correspondente - (Parecer) - in Pareceres 
- Rio de Janeiro - 1936 - volume III - pagina 257 I1-13-3.

361. Representação das sociedades anonimas - A quem compete representar as sociedades anonimas - São aplicaveis aos administradores os principios sobre o mandato mercantil (Parecer) - in Pareceres - Rio de Janeiro - 1934 - volume II - pagina 409 - I1-13-2.

362. Revogabilidade do mandato dos administradores das sociedades anonimas - A propriedade das ações é que dá o direito de votar assembléias geraes - (Parecer) - in Embargos ao accordam na apelação numero 8.333 - Rio de Janeiro 1933 - pagina 101 - S3-25-17.

363. Sociedade anonima - Alienação ou vinculação do direito de voto do acionista - Fato de manter, reeleger e não destituir dos respectivos cargos dois membros da diretoria - Clausula penal assecuratoria deste pacto - (Pareceres) - in Revista Forense - Belo Horizonte - 1928 - volume 51 - pagina 39 - M3-14-19.

364. Sociedades Anonimas - Alienação do voto de acionistas Inadmissibilidade - (Parecer) - in Revista de Direito Rio de Janeiro - 1928 - volume 87 - pagina 494 - N1-14-7.

365. Sociedades Anonimas - Aumento de capital - Reservas Imposto - (Parecer) - in Revista do Supremo Tribunal Rio de Janeiro - 1919 - vol. 18 - pagina 727 - 012-11-23.

366. Sociedade Anonima - Emissão de debentures - Garantia hipotecaria dos bens da sociedade - Inscrição especial a que se refere o art. 4 do decreto n. $177 \mathrm{~A}$ de 15 de setembro de 1893 - Quando não é necessaria - (Parecer) - in Revista de Direito - 1930 - volume 96 - pagina 274 - N1-14-16.

367. Sociedade anonima - Emissão de debentures - Garantia hipotecaria - Pagamento de juros - Annuncio - Efeito em relação ao portador de debentures - (Parecer) - in Revista de Direito - Rio de Janeiro - 1920 - volume 56 - pagina 36 - N1-15-3.

368. Sociedade anonima - Entrada de imoveis para a sua formação - Imposto de transmissão - Illegitimidade de sua co. brança - (Parecer) - in Revista de Direito - Rio de Janeiro - 1929 - volume 92 - pagina 458 - N1-14-12.

369. Sociedades anonimas extrangeiras - Exercicio de direitos no Brasil - Independencia da licença para funcionar no paiz - Licença para uso de marca extrangeira - Quando não importa na sua transferencia - Produto nacional - Quando deve ser assim considerado - Importação da materia prima 
- Indicação de falsa proveniencia - Quando não se verifica

- Ato arbitrario da autoridade fiscal - Proteção possessória

- (Pareceres) - in Revista de Direito- Rio de Janeiro. 1924 - volume 74 - pagina 319 - N1-15-22.

370. Sociedades anonimas - Resolução da Assembléia Geral modificando os estatutos - Como impellir os acionistas recalcitrantes a se submeterem á deliberação da Assembléia (Pareceres) - in Pandectas Brasileiras - Rio de Janeiro - 1928 - volume 4 - primeira parte - pagina 80 - H1-16-5.

371. Transferencia de açöes em sociedade anonima - "Mora solvendi" e "mora accipiendi" - (Parecer) - in Embargos numero 7.211 - São Paulo - 1914 - pagina 119 - N11-20-8.

372. Transformação de uma sociedade anonima em sociedade em comandita simples - Efeitos civis e efeitos fiscaes - (Pareceres) - in Revista de Direito - Rio de Janeiro - 1927 volume 86 - pagina 470 - N1-14-6.

373. Votação de reforma dos estatutos de sociedade anonima Como se apura a maioria necessaria para reforma de estatutos de sociedade anonima - (Parecer) - in Pareceres Rio de Janeiro - 1934 - volume II — pagina 309 - I1-13-2.

\section{Sociedades Comerciais.}

374. Alienação da parte de um socio na sociedade - nula a clausula que permite a um sócio retirar-se, vendendo a sua parte á sociedade, ou recusando esta, a terceiro - (Parecer) in Pareceres - Rio de Janeiro - 1934 - volume II — pág. 57 - 11-13-2.

375. Alienação de imoveis de uma sociedade — Os imoveis de uma sociedade podem ser por esta alienados, independente de um consentimento da mulher do socio - (Parecer) - in Pareceres - Rio de Janeiro - 1934 - volume II - pagina 45 I1-13-2.

376. Alienação do voto de acionistas - (Pareceres) - in Pandectas Brasileiras - Rio de Janeiro - 1927 - volume 2 - segunda parte - pagina 517 - H1-16-2.

377. Alterações do contrato de sociedade em comandita simples As modificações do contrato social, quando a entrada e saida de socios e a redução ou aumento de capital, não transforma a sociedade em comandita simples em sociedade de responsa. bilidade limitada - (Parecer) - in Pareceres - Rio de Janeiro - 1934 - volume II — pagina 269 - I1-13-2.

378. Banco - Falta de integralização de ações - Atos lesivos dos administradores - Obrigação de se fazer integralização - 
(Parecer) - in Revista dos Tribunaes - São Paulo - 1914 volume 10 - pagina $45-\mathrm{N} 5-17-10$.

379. Causas de dissolução de sociedade - Não havendo prazo estipulado, deve o socio entrar com a sua quota de capital desde a data do contrato. - Nesse caso si a sociedade se compóe apenas de dous socios, póde ser dissolvida - A clausula pela qual a quota de capital de um socio deve ser realizada com lucros não vale em relação a terceiros - Desinteligencia entre socios não é causa de dissolução da sociedade, salvo se provier de culpa inicial de um deles - (Parecer) - in Pareceres - Rio de Janeiro - 1934 - volume II — pagina 233 - I1-13-2.

380. A cessão de bens feita pelas sociedades comerciaes só compreende os bens do patrimonio social, e não os particulares dos associados - (Pareceres) - in O Direito - Rio de Janeiro - 1901 - volume 86 - pagina 43 - P-13-23-12.

381. Concurrencia desleal - Concurrencia desleal do socio que se retira de uma firma - (Parecer) - in Parecer - Rio de Janeiro - 1934 - volume II - pagina 393 - I1-13-2.

382. Confissão de um dos socios no periodo da liquidação - No periodo de liquidação não póde um socio confessar, obrigando os outros - (Parecer) - in Pareceres - Rio de Janeiro volume II - 1934 - pagina 313 - I1-13-2.

383. Conta de lucros e perdas na sucessão comercial - Á sociedade que sucede a uma firma individual passam as vantagens ou prejuizos verificados na conta de lucros e perdas - (Parecer) - in Pareceres - Rio de Janeiro — 1934 - volume II pagina 365 - I1-13-2.

384. Da responsabilidade dos trapicheiros e administradores de armazens de deposito - in Revista de comercio e Industria São Paulo - 1919 - volume 5 - pagina 141 - Q15-20-16.

385. Dissolução de firma social antes do prazo determinado por abuso do socio de industria e gerente em negocios extranhos á sociedade - Fôro de Santos - Ação ordinaria (Sentença) - in Razōes Finaes - Santos - 1889 - pagina 31 - S5-23-26.

386. Dissolução de socieđade - Pratica de um abuso que dá logar á dissolução da sociedade, o socio que aluga em proprio nome o prédio em que funciona a sociedade - Desinteligencia entre socios não é causa de dissolução da sociedade, salvo se provier da culpa inicial de um deles - (Parecer) - in Pareceres Rio de Janeiro - 1933 - volume II — pagina 247 - I1-13-2.

378. Distribuição dum fundo de reserva na dissolução das sociedades - O fundo social destina-se a fazer face a prejuizos futuros - Pertence á sociedade e não aos socios, e passam a 
um deles, se chama a si o ativo e o passivo da sociedade (Parecer) - in Pareceres - Rio de Janeiro - 1934 - volume II — pagina 47 - I1-13-2.

388. Distribuição de lucros suspensos no caso de aumento do capital da sociedade em comandita por ações - Os lucros suspensos de uma sociedade em comandita por ações que aumente o seu capital faz parte do patrimonio social, não podendo, portanto, ser distribuido entre antigos socios, com exclusão dos novos - (Parecer) - in Pareceres - Rio de Janeiro - 1934 volume II - pagina 257 - I1-13-2.

389. Escolha do liquidante - A nomeação do liquidante é feita livremente, por pluridade de votos - Não se aplicam, nessa materia, as disposições sobre suspeição e incompatibilidade (Parecer) - in Pareceres - Rio de Janeiro, 1934 - vol. II - pagina 25 - I1-13-2.

390. Firma comercial constituida apenas por iniciaes - $\mathbf{E}$ irregular a constituição de firmas comerciaes apenas por iniciaes - (Parecer) - in Pareceres - Rio de Janeiro - 1934 volume II - pagina 63 - I1-13-2.

391. Firma comercial - Mudança de nome de um dos socios para, adotando o do socio retirante, ser mantida a mesma razão (Pareceres) - In Revista Forense - Belo Horizonte - 1922 - volume 38 - pagina 143 - M3-14-6.

392. Fusão de sociedade - Cessão de carteira de companhia de seguros - Fusão - Direitos dos credores da sociedade encampada - Cessão de carteira de companhia de seguros - (Parecer) - in Pareceres - Rio de Janeiro - 1934 - volume II — pagina 13 - I1-13-2.

393. Inadmissibilidade de registro de firmas que se confundem $\mathrm{O}$ aditivo \& Cia. não é distintivo da firma nem evita a sua confusão com outra individual - (Parecer) - in Pareceres Rio de Janeiro - 1934 - volume II — pagina 333 - I1-13-2.

394. A lei deve regular a profissão de contador e estabelecer a sua intervenção obrigatoria na verificação dos balanços e contas das sociedades comerciaes $e$ anonimas e nas pericias judiciaes? — in Revista Forense - Belo Horizonte - 1923 - volume 41 - pagina 5 - M3-14-9.

395. Licença concedida pelo dono de marca para fabricação dos seus produtos - As sociedades extrangeiras não estão inibidas de formar com pessoas residentes no Brasil, quaisquer ajustes, desde que não ofendam as leis e os bons costumes - É erro supor que as marcas sómente pódem ser usadas por quem as registrou $-\mathrm{O}$ dono tem direito de conceder licença a terceiro 
para empregal-a em produtos que ela individualiza - Contra a apreensão ilegal desses produtos, pelo Fisco, póde ser requerida ação possessória - (Parecer) - in Pareceres - Rio de Janeiro - 1936 - volume III — pagina 303 - I1-13-3.

396. Liquidação de sociedade de acordo com a clausula contratual - (Parecer) - in Pareceres - Rio de Janeiro - 1934 - volume II - pagina 127 - I1-13-2.

397 Liquidação de sociedade - Balanço para liquidação com herdeiros de socio falecido - (Parecer) - in Pareceres - Rio de Janeiro - 1934 - volume II - pagina 297 - I1-13-2.

398. Liquidação de sociedade comercial - Erros nas contas aceitas Ação de socio - Prazo para prescrição - (Parecer) - in Revista dos Tribunaes - S. Paulo - volume 69 — pagina 333 - N5-15-4.

399. Liquidação de sociedade comercial - O fundo de reserva pertence a quem realiza o ativo e paga o passivo - Prescrição de direito e ação do socio para reclamar contra a forma de partilha adoptada na dissolução da firma - (Parecer) - in Ação e Reconvenção - São Paulo - 1909 - pagina 65 Q16-26.20.

400. Liquidação de sociedade comercial por morte ou retirada de qualquer socio - Não haverá violação nas clausulas contratuaes - (Parecer) - in Revista do Supremo Tribunal - Rio de Janeiro - 1915 - volume 5 - pagina 75 - O12-11-8.

401. Liquidação de sociedade comercial - Prescreve em dez dias a ação entre socios, ou contra liquidantes, quando fundada a lesão, ou na forma, ou divisão dos bens sociaes - E em vinte anos a ação dos socios entre si, fundada em dolo ou fraude (Parecer) - in Pareceres - Rio de Janeiro - 1934 - vol. II - pagina 113 - I1-13-2.

402. Liquidação de sociedade - O pagamento ao socio que se retira deve ser feito de conformidade com o balanço para verificação dos seus haveres, já aprovado, não participando ele dos lucros, nem assumindo elle responsabilidade proveniente das operaçōes subsequentes, realisadas durante o processo judicial da liquidação - (Parecer) - in Pareceres - Rio de Janeiro 1934 - volume II — pagina 293 - I1-13-2.

403. Liquidação de sociedade — Situação juridica dos herdeiros de um socio falecido que convencionam com os socios sobreviventes aguardar o vencimento do praso do contrato social, para procederem á liquidação - (Parecer) - in Pareceres Rio de Janeiro - 1934 - volume II - pagina 27 - I1-13-2.

404. O mandato conferido a uma pessoa juridica cessa com a extinção desta, porque a extinção das pessoas juridicas é equiparada 
á morte natural das pessoas fisicas - Mas não céssa com a simples dissolução, cabendo ao liquidante dar execução ao mandato (Parecer) - in Revista de Jurisprudencia Brasileira - Rio de Janeiro - 1930 - volume VII - pagina 476 C.345 (81) (05) 1 - 1930 - v. 7.

405. Morte da mulher de socio solidario - A morte da mulher de um socio, quer solidario, quer comanditario, não dissolve a sociedade - Nesse caso, si o regimen matrimonial era o da comunhão, devem os filhos aguardar a dissolução normal da sociedade para, depois de extintas as responsabilidades sociaes, se verificar o dividendo que, na partilha social, cabia a seu pae - O Direito dos socios sobre o fundo social e movel consiste em participar na partilha do liquido, depois de extinta a sociedade - (Parecer) - in Pareceres - Rio de Janeiro - 1934 - volume II - pagina 119 - I1-13-2

406. Natureza civil ou comercial de socỉedade - Não é o nome nem a fórma que dão o carater de civil ou comercial á sociedade - Solidariedade quer dizer garantia para os atos e operações sociaes - Esta garantia é oferecida a terceiros e não aos socios entre si - (Parecer) - in Parecer - Rio de Janeiro - 1934 - volume II - pagina 37 - I1-13-2

407. Nulidade de sociedade constituida com menores de 18 anos A contribuição de bens para formar o capital social constitue alienação - Nulidade da sociedade entre paes e filhos de 18 anos, embora com autorização do juiz - Nesse caso, ha sociedade de fato e a sua anulação só diz respeito ao futuro - Sociedade de fato se distingue de sociedade irregular (Parecer) - in Pareceres - Rio de Janeiro - 1934 - volume II - pagina 193 - I1-13-2.

408. Pacto pelo qual um socio assegura á sociedade um quinhão certo de lucro sobre determinado negocio - É valido o pacto pelo qual um socio assegura á Sociedade quinhão certo de lucro sobre determinado negocio - Esse pacto não é leonino - Em hipotese alguma póde, na constancia da sociedade, ser a divida de um socio descontada da sua quota de capital, porque pertence á sociedade - (Parecer) - in Pareceres - Rio de Janeiro - 1934 - volume II - pagina 185 - I1-13-2.

409. Pagamento de haveres de socio premorto - Os socios são co-proprietarios dos imoveis sociaes - Como se apuram e pagam os haveres do socio falecido - (Parecer) - in Pareceres - Rio de Janeiro - 1934 - volume II - pagina 277 I1-13-2.

410. Questão comercial - A quem se retira de uma Sociedade Comercial, cabe sómente o saldo verificado no balanço por 
ele mesmo aprovado, para efeito de servir de base á divisão dos haveres sociaes - (Parecer) - in Revista do Supremo Tribunal - Rio de Janeiro - 1920 - volume 23 - pagina $205-$ O2-11-27.

411. Eecomendavel o sistema da perpetuação das firmas comerciaes no caso de successão "mortis causa" ou "intervivos", ou convem manter o sistema do decreto $n .916$ de 4 de outubro de 1890, cujas bases assentam sobre a veracidade permanente das firmas, indicando estas pelo menos o nome por extenso ou abreviado do seu titular ou de um dos socios de responsabilidade ilimitada? - in Revista Forense - Belo Horizonte 1923 - volume 41 - pagina 7 .

412. Reforma de estatutos - Não pódem os estatutos, na parte em que conferem direitos especiaes, contratuaes, a socios ser modificados, sem assentimento destes - A limitação dos poderes das assembléias é principio aceito se mdiscrepancia (Parecer) - in Pareceres - Rio de Janeiro - 1934 - volume II — pagina 55 - I1-13-2.

413. Representaça da sociedade por um dos socios, na queixa crime - Queixa-crime oferecida por um socio, em nome da firma - Como deve assinar o socio que em nome da firma assiste aos depoimentos tomados em juizo - (Parecer) - in Pareceres - Rio de Janeiro - 1936 - volume III — pagina 215 - I1-13-3.

414. Responsabilidade dos socios nas sociedades por quotas - A responsabilidade limitada dos socios, nas sociedades por quotas firma-se desde o dia do arquivamento do contrato - Transformação de sociedade em nome coletivo em sociedade por quotas - (Parecer) - in Pareceres - Rio de Janeiro 1934 - volume II - pagina 343 - I1-13-2.

415. Sociedade de capital e industria - É solidario o socio de industria que, no contrato social, tem poderes de gerencia, mas essa solidariedade se opera unicamente em relação a terceiros (Parecer) - in Pareceres - Rio de Janeiro - 1934 - volume II — pagina 283 - I1-13-2.

417. Sociedade em comandita simples - O comanditario pode ter retiradas por conta de despesas geraes - Sua situação na falencia, quanto aos lucros que lhe estão creditados - (Parecer) - in Pareceres - Rio de Janeiro - 1934 - volume II pagina 5 - I1-13-2.

418. Sociedade em comandita por ações - Falecimento de um dos socios gerentes da sociedade em comandita por ações impossivel modificação do contrato de sociedade dessa natu- 
reza, sem expressão assentimento dos socios solidarios - (Parecer) - in Pareceres - Rio de Janeiro - 1934 - volume II - pagina 221 - I1-13-2.

419. Sociedade comercial - Desde que tenha direito ao uso da firma, o socio, embora empregando-a abusivamente, torna responsavel a sociedade - (Parecer) - in Pareceres - Rio de Janeiro - 1934 - volume II - pagina 31 - I1-13-2.

420. Sociedade Comercial por tempo indeterminado - Clausula contratual que confere ao socio chefe, a faculdade de fazer quaisquer alteraçōes no contrato e de pôr a retirada de algum sócio - Validade - Dissolução parcial - (Parecer) - in Revista de Direito - Rio de Janeiro - 1930 - volume 96 - pagina 67 - N1-14-16.

421. Sociedade Comercial - Socios - Falencia individual - Quando não admissivel - in Revista de Direito - Rio de Janeiro - 1909 - volume 13 - pagina 65 - N1-17-13.

422. Sociedade em conta de participação e locação de serviços Caracteristicas da sociedade em conta de participação e distinção da locação de serviços - Não é da essência do mutuo em dinheiro o curso de juros - (Parecer) - in Pareceres - Rio de Janeiro - 1934 - volume II - pagina 347 - I1-13-2.

423. Sociedade em conta de participação e comissão mercantil Distinção entre sociedade em conta de participação e comissão mercantil - (Parecer) - in Pareceres - Rio de Janeiro 1933 - volume I - pagina 197 - I1-13-1.

424. Sociedade extrangeira - Capacidade para contratar - Estabelecimento de filiaes ou sucursaes - Autorização - Poderes geraes de administração - Representação em Juizo - Documentos em lingua extrangeira - Tradução - Exibição do original - Compra e Venda - Recusa de mercadoria Quando não é necessaria a interpelação - Obrigações comerciaes sem prazo - Vencimento - Cousa vendida - Diversidade da amostra - A quem incumbe a prova - Deposito da cousa vendida - Quando sómente é necessario - Contrato por correspondencia - Formação - (Pareceres) - in Revista de Direito - Rio de Janeiro - 1924 - volume 74 - pagina 475 - N1-15-22.

425. Sociedade irregular - torna-se irregular a sociedade que continua a operar depois de expirado o prazo contratual - (Parecer) - in Pareceres - Rio de Janeiro - 1934 - volume II - pagina 223 - I1-13-2.

426. Sociedade - Liquidação - Aceitação do inventario e balanço por parte dos socios - Forma de liquidação - Pedido de lei- 
lão - Denegação - Recurso - Não provimento - Lucros ou prejuízos verificados posteriormente áquela aceitação do ba. lanço - Haveres já verificados - Importancias a que tem direito o socio - recorrente - (Pareceres) - in Revista de Direito - Rio de Janeiro — 1919 - volume 54 - pagina 221 N1-15-1.

427. Sociedade por quota - Póde adotar a denominação "Companhia"? - in Revista Forense - Belo Horizonte - 1928 volume 51 - pagina 39 - M3-14-19.

428. Sociedade por tempo indeterminado - in Pareceres - Rio de Janeiro - 1934 - volume II - pagina 149 - I1-13-2.

429. Sociedades Comerciaes - Transformação de sociedade anonima em companhía simples - Subrogação de obrigações - Imposto de selo - Fundo de reserva - Imposto de transmissão (Pareceres) - in Revista dos Tribunaes - São Paulo — 1927 - vol. 64 - paginas 33 e 38 - N5-16-29.

430. Sociedades extrangeiras - As sociedades anonimas extrangeiras dependem de autorização do governo para funcionarem no paiz, mas independentemente dessa autorização podem celebrar contratos exequiveis no Brasil e acionar os seus devedores residentes na Republica - (Parecer) - in Pareceres - Rio de Janeiro - 1936 - volume III — pagina 275 - I1-13-3.

431. Podem as Sociedades Anonimas por quotas adoptar a denominação "Companhia"? - in - Pandectas Brasileiras Rio de Janeiro - 1926 - volume primeiro - 1. ${ }^{\mathrm{a}}$ parte pagina 79 - H1-16-1.

432. Sociedade por quotas de responsabilidade limitada - Não pódem adoptar a denominação "companhia" - (Parecer) in Revista de Direito — Rio de Janeiro — 1927 - volume 83 - pagina 466 - N1-14-3.

433. Socios comanditarios - O fato de conceder o contrato social ao socio comanditario o direito de assumir a gerencia, quando quizer, não o torna solidario, se de fato ela não praticou atos de gestão - Tambem não o torna solidario o fato de lhe dar o contrato social uma retirada por conta de despesas geraes, mas as quantias por esse titulo recebidas devem ser restituidas á Sociedade - (Parecer) - in Pareceres - Rio de Janeiro - 1934 - volume II — pagina 75 - I1-13-2.

434. Socios gerentes das sociedades em comandita - Os socios gerentes das sociedades em comandita não pódem ser destituidos pelo poder judiciario, mas sómente pela assembléia geral dos comanditarios nos casos cogitados nos estatutos ou 
na lei - in Sergipe Judiciário - Aracajú - Sergipe - 1928 - vol. 1 - pagina 155 - S13-25-4.

435. Socios gerentes das sociedades em comandita - in Revista de Direito - Rio de Janeiro - 1928 - volume 88 - pagina 267 - N1-14-8.

436. Sucessão de firma comercial - Requisitos para que uma firma comercial possa conter a indicação de que é successora de outra - (Parecer) - in Pareceres - Rio de Janeiro 1936 - volume III — pagina 71 - I1-13-3.

437. Transferencia do um estabelecimento industrial - Cessão da clientela ou frequencia - Concorrência desleal - Lide temeraria - Indenização por perdas e danos - Gazeta Juridica - São Paulo, 1911 - volume 57 - pagina 133 - R16-22-11.

438. Transformação de sociedade em comandita em sociedade irregular - Terminado o prazo da sociedade em comandita simples, sem que tenha haviđo alteração ou renovação do contrato, ella se transforma em irregular - Si a sociedade está dissolvida, não póde ser alterado o contrato que se extinguiu, e muito menos prorrogado o prazo para a sua putação (Pareceres) - in Pareceres - Rio de Janeiro - 1936 volume III - pagina 269 - I1-13-3.

439. Transformação da sociedade em comandita simples em sociedade de fato - Se a sociedade em comandita simples continua a operar depois de terminado o prazo estabelecido no contrato social, ela se transforma em sociedade de fato, em que todos os socios tem responsabilidade ilimitada e solidária - Desde então, apezar do registro da firma declarar quaes os socios que pódem assinal-a, todos passam a ter o seu uso - (Parecer) - in Pareceres - Rio de Janeiro - 1936 - volume III - pagina 292 - I1-13-2.

440. Transformação de sociedades - A transformação da sociedade de responsabilidade ilimitada em sociedade de responsabilidade limitada não prejudica direitos de terceiros - (Parecer) in Pareceres - Rio de Janeiro - 1934 - volume II — pagina 253 - I1-13-2.

441. Uso da firma em negocios da sociedade — valida a constituição de penhor e subsequente doação em pagamento e arrendamento dos maquinismos de uma fabrica desde que as escripturas tenham sido feitas para negocios sociaes, embora outorgadas apenas por um dos sócios que assinam a firma social - (Parecer) - in Pareceres - Rio de Janeiro - 1934 - volume II - pagina 69 - I1-13-2. 


\section{Processo.}

442. Abalroação - Fôro competente para a seção de indenização - Competencia do agente, ou consignatário, para receber a citação inicial, quaisquer que sejam as restrições dos seus poderes - (Parecer) - in Pareceres - Rio de Janeiro - 1936 - volume III - pagina 95 - I1-13-3.

443. A apelação nas ações sumárias de reclamação de crédito, de que trata o artigo 860 do codigo comercial, deve ser recebida em ambos os efeitos? - in O Direito - Rio de Janeiro - 1888 - volume 47 - pagina 165 - P9-23-25.

444. Dies a quo - (Pareceres) - in Revista do Supremo Tribunal Rio de Janeiro - 1916 - volume 9 - pagina 131 - 012-11-12.

445. O domicilio da União - in Revista dos Tribunaes - São Paulo - 1916 - volume 19 - pagina 282 - N5-17-19.

446. Embargos de terceiros prejudicado - o terceiro prejudicado que não apelou da sentença, por não ter conhecimento do feito, póde embargar - (Parecer) - in Revista Forense - Belo Horizonte - 1904 - volume 2 - pagina 18 - M2-14-1.

-447 Exame de livros do cedente - No litigio entre cessionario e devedor pódem ser examinados os livros do cedente, a requerimento deste ou daqueles - (Parecer) - in Pareceres - Rio de Janeiro - 1936 - volume III - pagina 334 I1-13-3.

448. Executivo hipotecario - Extrato de conta corrente - (Pareceres) - in Revista Forense - Belo Horizonte - 1928 volume 50 - pagina 32 - M3-14-18.

449. Executivo hipotecario - Falta de licitante na terceira praça - Como proceder - (Parecer) - in Revista Forense - Belo Horizonte - 1911 - volume 15 - pagina 18 - M2-14-13.

450. Fraudes de despachante - Responde o mandante pelos atos culposos. dolosos, fraudulentos ou delituosos do mandatario - Pelos atos fraudulentos do despachante, contra o fisco, deixa de responder o comitente, quando esses tiveram a cooperação indispensavel dos empregados fiscaes - (Parecer) - in Pareceres - Rio de Janeiro - 1936 - volume III - pagina 31 11-13-3.

451. Penhor de todos os bens imoveis de um estabelecimento comercial - Meios de impugnal-os entre revisora e ação revocatoria - (Parecer) - in Revista Forense - 1916 - volume 26 - pagina 465 - M2-14-24. 
452. Pluralidade de autores - Ações Cumulação - in Revista de Direito - Rio de Janeiro - 1909 - volume 13 - pagina 469 N1-17-13.

453. Um prazo de 3 mezes não é contado como se fosse de noventa dias - Prazo para a apresentação dos autos no tribunal de apelação de São Paulo; excepção a favor de menores; impedimento que justificam a prorrogação deste prazo; embaraço de juizo, o que é, e si póde prejudicar á parte (Parecer) - in 0 Direito - Rio de Janeiro - 1905 - volume 97 - pagina 304 P13-23-23.

454. Recurso extraordinario - Efeitos da decisão proferida em conflito de jurisdição - (Pareceres) - in Revista Forense Belo Horizonte - 1911 - volume 15 - pagina 244 - M2-14-23.

455. O terceiro prejudicado que não apelou da sentença, por não ter conhecimento do feito, póde embargar? - (Parecer) - in Embargos de terceiro prejudicado - São Paulo, 1904 - S5-23-4.

456. O terceiro prejudicado que não apelou da sentença, por não ter conhecimento do feito, póde embargar? - in Revista de Direito - Rio de Janeiro - 1908 - vol. 7 - pagina 474 N1-17-7.

457. Vendas judiciaes em hasta publica - Questões respectivas (Parecer) - in Revista Juridica - Porto Alegre - 1901 volume 6 - pagina 30 - S14-24-15.

\section{Diverses.}

458. J X. Carvalho de Mendonça e a Faculdade de Direito de São Paulo - in Revista da Faculdade de Direito - São Paulo 1951 - volume XLVI - pagina 52 - 34(81.41) (05) - 1951 S.C.

459. Discurso, no Instituto da Ordem dos Advogados de São Paulo, por ocasião da posse no cargo de socio-honorario - in Revista dos Tribunaes — São Paulo - 1925 - volume 56 - pagina 39 - N5-16-21.

460. Discurso proferido ao ser recebido como membro honorario do Instituto da Ordem dos Advogados de São Paulo - in Boletim do Instituto da Ordem dos Advogados Brasileiros Rio de Janeiro - nova série - 1927 - volume I — Maio a Dezembro - pagina 307 - Q13-15-2.

461. Instituto da Ordem dos Advogados — Sessão solene em 10 de outubro de 1928, em homenagem ao Dr. J. X. Carvalho de Mendonça - in Revista dos Tribunaes - São Paulo - 1929 — volume 72 - paginas 296 a 303 - N5-15-7. 
462. O Juiz de Paz suspenso deve ser eliminado da respectiva lista, completando-se esta com o $1 .^{\circ}$ imediato em votos ao $4^{\circ}$ juiz eleito? - in O Direito - Rio de Janeiro - 1888 - volume 47 - paginas 339 - P9-23-25.

463. Justificação de perda de titulo de eleitor - in O Direito Rio de Janeiro 1886 - volume 41 - pagina 513 - P9-23-19.

464. Oração do Apostolo - in Revista de Critica Judiciaria - Rio de Janeiro - 1926 - volume 2 - pagina 191 - 04-16-3.

465. Prefácio de "Sentenças" de Chrysolito de Gusmão - in Sentenças — Rio de Janeiro - 1931 - pagina 5 - S14-12-25. 